\title{
Latest Updates on the Advancement of Polymer-Based Biomicroelectromechanical Systems for Animal Cell Studies
}

\author{
Ricardo Garcia-Ramirez, ${ }^{1}$ Ana S. Cerda-Kipper, ${ }^{1}$ Damaris Alvarez, ${ }^{1}$ Sofia Reveles-Huizar, ${ }^{1}$ \\ Jorge A. Garza-Abdala, ${ }^{1}$ and Samira Hosseini $\mathbb{1}^{1,2}$ \\ ${ }^{1}$ Tecnologico de Monterrey, Writing Lab, Institute for the Future of Education, Monterrey, 64849 NL, Mexico \\ ${ }^{2}$ Tecnologico de Monterrey, Institute for the Future of Education, Institute for the Future of Education, Monterrey, 64849 NL, Mexico \\ Correspondence should be addressed to Samira Hosseini; samira.hosseini@tec.mx
}

Received 1 September 2020; Revised 6 March 2021; Accepted 24 March 2021; Published 7 April 2021

Academic Editor: Kinga Pielichowska

Copyright ( 2021 Ricardo Garcia-Ramirez et al. This is an open access article distributed under the Creative Commons Attribution License, which permits unrestricted use, distribution, and reproduction in any medium, provided the original work is properly cited.

\begin{abstract}
Biological sciences have reached the fundamental unit of life: the cell. Ever-growing field of Biological Microelectromechanical Systems (BioMEMSs) is providing new frontiers in both fundamental cell research and various practical applications in cellrelated studies. Among various functions of BioMEMS devices, some of the most fundamental processes that can be carried out in such platforms include cell sorting, cell separation, cell isolation or trapping, cell pairing, cell-cell communication, cell differentiation, cell identification, and cell culture. In this article, we review each mentioned application in great details highlighting the latest advancements in fabrication strategy, mechanism of operation, and application of these tools. Moreover, the review article covers the shortcomings of each specific application which can open windows of opportunity for improvement of these devices.
\end{abstract}

\section{Introduction}

The analytical platforms that facilitate growing, monitoring, analyzing, and manipulating cells are essential to the advancements of the biological and biomedical fields [1]. In cell-related studies, it is of vital importance to be able to identify, isolate, sort and separate, culture, pair, and record the differentiation and communications of cells. While 2dimensional (2D) in vitro platforms enable a certain degree of progress, they fall short in mimicking the microenvironment the cells experience within a living body [2]. Moreover, cell studies within traditional petri dish commonly require large sample volume and various external equipment to support the experiments. Biological Microelectromechanical Systems (BioMEMSs) have emerged as great alternatives to facilitate cell studies for multiple applications. These devices are compact and portable while operating on small sample volume and offering automatization of multiple processes.

Application of BioMEMS in cell-related studies allows metering, dilution, flow switching, particle separation, mix- ing, pumping, incubation of reaction mixtures, and dispensing or injecting cells for different procedures [2]. BioMEMS closely mimics microenvironment of cells by incorporating the necessary stimulations of physical, electrical, chemical, and mechanical natures that cells need in order to grow and respond to their surroundings. The intrinsic properties of cells including size, shape, deformability, and charge play a crucial role in physically manipulating them $[3,4]$. These devices rely on several forces including electrical, magnetic, mechanical, hydrodynamic, and centrifugal forces to manipulate cells for intended applications. Fabrication of BioMEMS commonly follows the standard soft or hard lithography techniques often combined with lift-off, wet etching, replica modeling, and 3-dimensional (3D) printing. Polymers, in particular, have played a significant role in fabrication of these devices as they lend remarkable characteristics to the device including flexibility, transparency, lightweight, ease of fabrication, and cost-effectiveness [5].

In this review article, the latest advancements of polymerbased BioMEMS in cell-related studies are summarized. In 


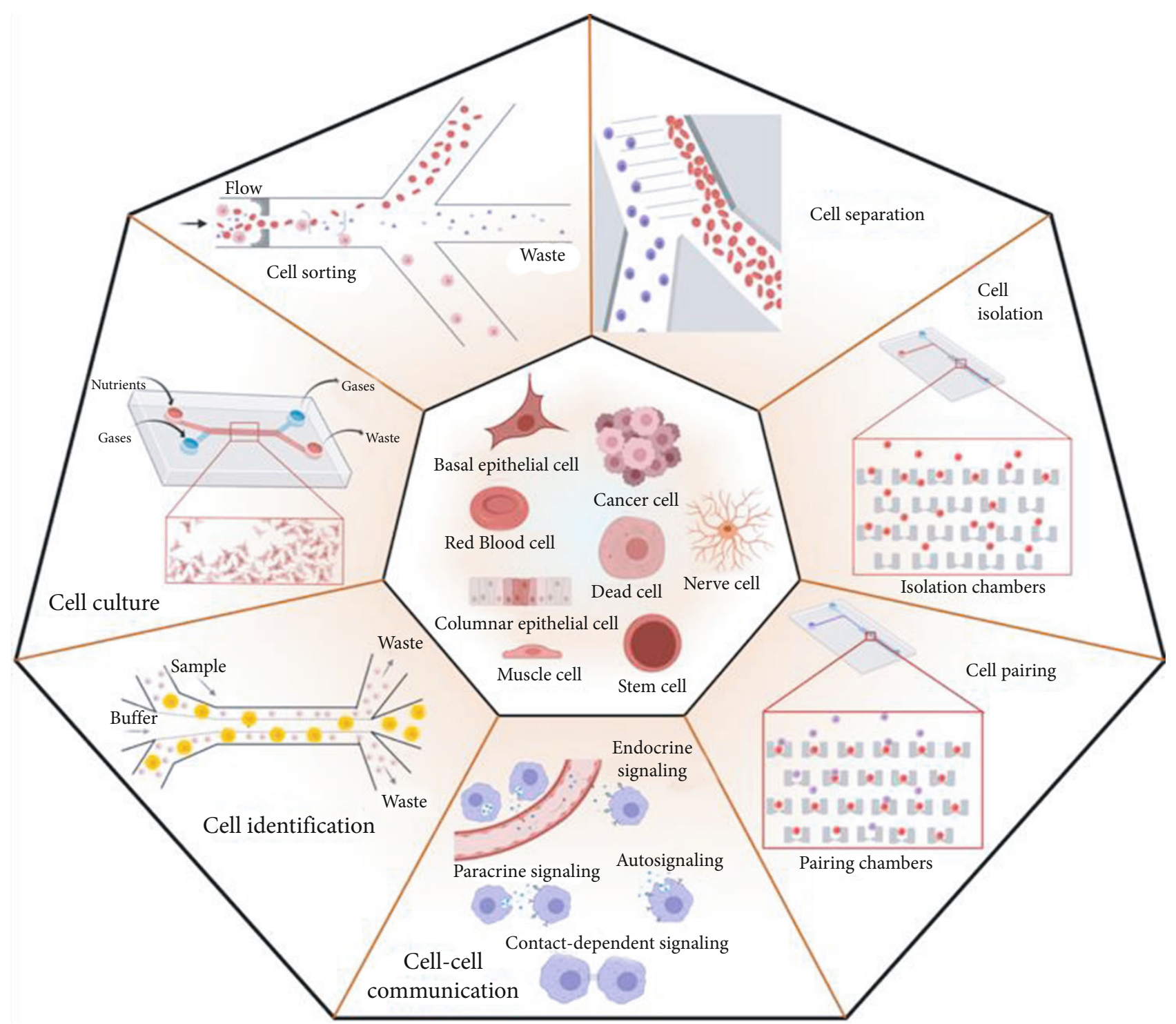

FIGURE 1: Cell-related applications of BioMEMS: cell sorting, cell separation, cell isolation, cell pairing, cell-cell communication, cell identification, and cell culture.

specific, applications such as cell sorting, cell separation, cell isolation or trapping, cell pairing, cell-cell communication, cell differentiation and identification, and cell culture in latest designs of BioMEMS are thoroughly reviewed (Figure 1). Each field of study includes the latest updates of the BioMEMS along with their main components, the fabrication strategy, the mechanism of operation, and the specifics of each platform. The review article also covers limitations and shortcoming of BioMEMS in cell-related studies with specific emphasis on the applications of interest.

\section{BioMEMS in Cell Sorting}

Accurate and high-throughput particle/cell sorting is a critical step in various protocols in biology, biotechnology, and medicine [6]. Nowadays, conventional technologies are capable of providing high-efficiency sorting in a short timescale. Recent advances in BioMEMS have allowed the development of miniaturized devices offering similar capabilities as those provided by commercial cell sorting platforms [7]. Cell sorting on BioMEMS provides several advantages, including the reduction of the equipment size, eliminating potential hazardous aerosols, simplifying complex protocols, and multiplexing several steps [8]. BioMEMSs dedicated to particle or cell sorting are capable of integrating time-consuming and labor-intensive experimental procedures into compact integrated pieces of equipment. These devices manipulate small sample volumes that allow examining individual cells or particles of interest $[6,9]$. Table 1 presents some of the latest applications of BioMEMS devices in cell sorting in detail providing the components of the device, the fabrication strategy, and the mechanism of operation, in addition to the specific and remarks for these devices.

The intrinsic physical properties of the target cells are often used to achieve controlled cell sorting. The use of external charges or forces is introduced to BioMEMS in order to 
TABLE 1: Recent BioMEMS platforms for particle/cell sorting including the type of the platform, the main components, the fabrication strategy, the mechanism of operation, and the specifics of each platform.

\begin{tabular}{|c|c|c|c|c|c|}
\hline BioMEMS platform & Main components & $\begin{array}{c}\text { Fabrication } \\
\text { strategy }\end{array}$ & Mechanism of operation & Specifics & Ref. \\
\hline $\begin{array}{l}\text { Microfluidic-based } \\
\text { Raman ACS }\end{array}$ & $\begin{array}{c}\text { Laser beam laser } \\
\text { tweezer Raman } \\
\text { microscopy PDMS- } \\
\text { based microfluidic } \\
\text { device }\end{array}$ & $\begin{array}{l}\text { Standard soft } \\
\text { lithography } \\
\text { technique }\end{array}$ & $\begin{array}{l}\text { Raman effect takes place when } \\
\text { light illuminates a certain region } \\
\text { of the microdevice. The photon } \\
\text { interaction perturbs the electron } \\
\text { configuration of the molecule to } \\
\text { an unstable virtual state during } \\
\text { the photon scattering, yielding the } \\
\text { differences between particles. }\end{array}$ & $\begin{array}{l}\text { The laser tweezers enable } \\
\text { trapping of individual cells at the } \\
\text { focus of the laser beam. }\end{array}$ & {$[15]$} \\
\hline $\begin{array}{l}\text { Micro/nanomotors } \\
\text { for cancer cell } \\
\text { targeting }\end{array}$ & $\begin{array}{l}\text { Synthesized PS } \\
\text { Janus particles }\end{array}$ & $\begin{array}{l}\text { Wet etching and } \\
\text { photolithography }\end{array}$ & $\begin{array}{c}\text { The micromotors were designed } \\
\text { to harness local } \mathrm{H}_{2} \mathrm{O}_{2} \text { produced } \\
\text { by cancer cells to convert chemical } \\
\text { energy into mechanical } \\
\text { propulsion while targeting specific } \\
\text { cancer cells. }\end{array}$ & $\begin{array}{l}\text { The design needs to overcome the } \\
\text { low Reynolds number and } \\
\text { Brownian motion, which work } \\
\text { together against the motor's } \\
\text { locomotion. }\end{array}$ & [14] \\
\hline $\begin{array}{l}\text { Centrifugal } \\
\text { microfluidic Chip }\end{array}$ & $\begin{array}{l}\text { Charge-based } \\
\text { microchannel flow }\end{array}$ & Standard soft & $\begin{array}{l}\text { By applying a voltage to the cells, } \\
\text { monodisperse droplets were } \\
\text { generated and manipulated. }\end{array}$ & $\begin{array}{l}\text { The device encapsulates and sorts } \\
\text { cells in one single step. }\end{array}$ & {$[10]$} \\
\hline $\begin{array}{l}\text { Single-molecule } \\
\text { tracing microfluidic } \\
\text { chip }\end{array}$ & $\begin{array}{l}\text { Microchannels } \\
\text { Acoustic wave } \\
\text { transducer }\end{array}$ & lithography & $\begin{array}{l}\text { Acoustic waves push specific } \\
\text { particles into cavities depending } \\
\text { on their size and deformability. }\end{array}$ & $\begin{array}{l}\text { The device can be used for } \\
\text { organic and inorganic particle } \\
\text { separation. }\end{array}$ & [11] \\
\hline $\begin{array}{l}\text { 3D carbon-DEP } \\
\text { microfluidic chip }\end{array}$ & $\begin{array}{l}\text { 3D-carbon } \\
\text { electrodes voltage } \\
\text { signal generator }\end{array}$ & $\begin{array}{c}\text { Two-step } \\
\text { photolithography } \\
\text { process }\end{array}$ & $\begin{array}{l}\text { DEP was used to separate death } \\
\text { from live monocytes using } 3 \mathrm{D} \\
\text { carbon electrodes. A voltage was } \\
\text { applied to create an electric field. } \\
\text { Live monocyte cells reacted to the } \\
\text { attraction force and were trapped } \\
\text { in the electric fields near the } \\
\text { electrodes while dead cells remain } \\
\text { unresponsive. }\end{array}$ & $\begin{array}{l}\text { The strategy offers a contact-free } \\
\text { procedure leading to more } \\
\text { accurate analytical results. }\end{array}$ & [17] \\
\hline $\begin{array}{l}\text { DEP microfluidic } \\
\text { chip }\end{array}$ & $\begin{array}{l}\text { ITO electrodes } \\
\text { Function generator } \\
\text { Power supply } \\
\text { Syringe pump } \\
\text { Microfluidic device }\end{array}$ & $\begin{array}{l}\text { Standard soft } \\
\text { lithography }\end{array}$ & $\begin{array}{l}\text { Following the channels, the cells } \\
\text { were carried to the tumor- } \\
\text { trapping zone, where tumor cells } \\
\text { could not continue traveling } \\
\text { through the device outlet due to } \\
\text { their size and deformability. }\end{array}$ & $\begin{array}{l}\text { The device is capable to induce } \\
\text { cell sorting based on DEP by } \\
\text { encapsulating particles in } \\
\text { droplets and applying a voltage } \\
\text { potential in a single step. }\end{array}$ & [18] \\
\hline $\begin{array}{l}\text { Microfluidic-based } \\
\text { Raman ACS } \\
\text { optofluidic } \\
\text { platform }\end{array}$ & $\begin{array}{l}\text { Raman } \\
\text { microspectroscopy } \\
\text { Laser beams } \\
\text { Laser tweezers } \\
\text { PDMS-based } \\
\text { microfluidic device }\end{array}$ & $\begin{array}{l}\text { Standard soft } \\
\text { lithography }\end{array}$ & $\begin{array}{l}\text { Cells from a sample fluid were } \\
\text { flown into a microfluidic device } \\
\text { and focused in the vertical and } \\
\text { horizontal directions by two } \\
\text { sheath flows. Cells captured by the } \\
\text { optical tweezers were moved to } \\
\text { the sample-free stream for } \\
\text { spectrum measurement. Cells of } \\
\text { interest were released into the } \\
\text { collection outlet for further } \\
\text { cultivation. }\end{array}$ & $\begin{array}{l}\text { The device is capable of sorting } \\
\text { four model bacteria while } \\
\text { demonstrated a sorting accuracy } \\
\text { of } 98 \% \text {, high-throughput } \\
\text { performance by sorting up to } 500 \\
\text { cells per hour, and compatibility } \\
\text { with cultivation after collection of } \\
\text { the cells. }\end{array}$ & [16] \\
\hline $\begin{array}{l}\text { DEP microfluidic } \\
\text { chip }\end{array}$ & $\begin{array}{l}\text { Au/Ti electrodes } \\
\text { Function generator } \\
\text { Power supply } \\
\text { Syringe pump } \\
\text { PDMS-based } \\
\text { microfluidic device }\end{array}$ & $\begin{array}{l}\text { Standard soft } \\
\text { lithography, } \\
\text { physical vapor } \\
\text { deposition, and } \\
\text { D.C. sputtering }\end{array}$ & $\begin{array}{l}\text { A sample was injected in the } \\
\text { microfluidic chip at a constant } \\
\text { rate, following through the } \\
\text { channels; the cells of interest were } \\
\text { subjected to DEP forces and } \\
\text { trapped in different areas. }\end{array}$ & $\begin{array}{l}\text { The device is capable of } \\
\text { separating three kinds of } \\
\text { circulating cells. The proposed } \\
\text { model for DEP-based cell } \\
\text { stretching enables the integration } \\
\text { of more reliable geometries that } \\
\text { can potentially optimize the use } \\
\text { of DEP for cell sorting. }\end{array}$ & {$[20]$} \\
\hline
\end{tabular}


TABLE 1: Continued.

\begin{tabular}{lcccc}
\hline BioMEMS platform & Main components & $\begin{array}{c}\text { Fabrication } \\
\text { strategy }\end{array}$ & Mechanism of operation & Specifics \\
\hline $\begin{array}{l}\text { DEP microfluidic } \\
\text { chip with } \\
\text { conductive PDMS }\end{array}$ & $\begin{array}{c}\text { Ag-PDMS-based } \\
\text { electrodes } \\
\text { Power supply } \\
\text { PDMS microfluidic } \\
\text { chip }\end{array}$ & $\begin{array}{c}\text { Standard soft } \\
\text { lithography and } \\
\text { multilayer } \\
\text { lithography }\end{array}$ & $\begin{array}{c}\text { Sorting was achieved by DEP } \\
\text { forces while a solution of cells } \\
\text { passed through the microfluidic } \\
\text { device. }\end{array}$ & $\begin{array}{c}\text { The device utilizes Ag-PDMS } \\
\text { process. DEP is utilized at low DC } \\
\text { voltages of less than 15 Vpp with } \\
\text { a high frequency. }\end{array}$ \\
\hline
\end{tabular}

ACS: activated cell sorting; Ag-PDMS: silver-polydimethylsiloxane; CTCs: circulating tumor cells; DEP: dielectrophoresis; $\mathrm{H}_{2} \mathrm{O}_{2:}$ hydrogen peroxide; ITO: indium tin oxide; LOC: Lab-on-a-Chip; PDMS: polydimethyl siloxane; PS: polystyrene; RACS: Raman activated cell sorting; Vpp: peak to peak voltage (Vpp); 3D: three dimensional.

achieve a fine sorting of particles. A microscale centrifugal technology called centrifugal microfluidic chip (CMC) was developed by Yu et al. The authors describe a device capable of classifying immune cells from the blood cells based on their charge and performing a cell analysis in situ. The CMC consists of a glass-sandwich channel-layer assembly with an integrated polydimethylsiloxane (PDMS) layer along with microfluidic channels that connect the two glass layers. This glass-sandwich approach was used to enhance the CMC mechanical properties and minimize the deformation of the PDMS channels at higher centrifugation speeds. Since the glass tensile strength is higher than that of PDMS, the authors were able to achieve an acceleration of $1,000 \mathrm{~g}$ without damaging the microfluidic PDMS channels while enabling a higher recovery of peripheral blood mononuclear cells (PBMC). A simple 10-minute centrifuge step was necessary to reach purity and recovery levels above $95 \%$ for PBMC [10]. This implementation yields several applications related to the automatization of blood sample assays and could potentially be utilized to develop point-of-care (POC) devices for rapid diagnostics.

A device capable of controlling the movement of different particles using surface acoustic waves (SAWs) was developed by Lin et al. [9]. The device employed a digital transducer to generate different sound waves that enabled the movement of particles of specific sizes in predefined pathways. The sound waves directed the particles into separate cavities, enabling the individual analysis of these targeted particles [9]. The PDMS chamber of the device was fabricated on a silicon (Si) mold etched by deep reactive ion etching and molded using conventional soft lithography techniques. Demolding from the Si wafer was achieved by finalizing the etching process with a passivation step to yield a hydrophobic surface layer on the PDMS. Diverse sound waves can be generated providing a basis for the device to work with an extensive range of particles (inorganic and organic), thus allowing it to be used for several applications related to cell studies including cell differentiation and stress research, among others [9].

Another example of a BioMEMS applying SAW for cell sorting is the work of Ding and Huang which utilized tunable standing surface acoustic waves (SSAWs) in a continuous flow to separate white blood cells. The main difference between the proposed work of Lin et al. and this work is the use of the acoustic radiation force to directly manipulate cells, rather than affecting the fluids [11]. The authors described the use of a single-layer PDMS channel and a piezoelectric substrate with a pair of interdigitated transducers as part of the device. PDMS is often used as the preferred polymer for BioMEMS and cell studies due to its beneficial features including optical transparency, biocompatibility, low autofluorescence, deformability, low electromagnetic energy dissipation, and high dielectric strength, among others [12]. Nevertheless, it has been reported that the thickness of PDMS walls could directly affect the transmission of the SAW. For that reason, it is recommended that microfluidic channel walls to be as thin as possible to enhance the efficiency of the SAW-based devices [13].

BioMEMS devices focused on particle or cell sorting are an enabling technology to automate and integrate multistep operations. The use of MEMS technologies significantly reduces the total time of an assay in applications related to diagnostics and drug-delivery systems (DDS). Gao et al. described a technique for cell sorting based on micro/nanomotors, which were equipped with in situ energy conversion that made them capable of autonomous movement. The ability of some cancer cells to mutate, inhibit antiproteases, and result in metastasis involves generating oxidative stress by producing an elevated level of hydrogen peroxide $\left(\mathrm{H}_{2} \mathrm{O}_{2}\right)$. The authors used this fact as the principle for designing the device. The micromotors were designed to harness local $\mathrm{H}_{2} \mathrm{O}_{2}$ produced by cancer cells to convert chemical energy into mechanical propulsion while targeting specific cancer cells. Presented mechanism with the propelled navigation allows micro/nanomotors to act as highly diffusive delivery vehicles that promote cancer cell targeting with possible applications related to DDS and cancer diagnostics by the aim of specific biomarkers [14].

The single-cell Raman spectra (SCRS) is often utilized to characterize phenotypic changes and functions of cells of interest. Song et al. described the development of a Raman activated cell sorting (RACS) device with no external labeling [15]. Furthermore, Lee and colleagues in 2019 described a Raman-based cell sorting technique with 3D microfluidics. In this work, a 3D hydrodynamic focusing microfluidic system for a fully automated, continuous Raman activated cell sorting (3D-RACS) was described. The system consisted of 3D printed detection chambers that have been integrated within a PDMS-based sorting unit. The device demonstrated the ability to precisely position cells in the detection chamber 
for Raman measurements and sorting from $1 \mu \mathrm{m}$ to $10 \mu \mathrm{m}$ cell sizes [16].

Another sorting approach that uses a label-free method and has been continuously used due to its relevant characteristics is dielectrophoresis (DEP). DEP is often referred to as one of the most utilized sorting methods since it preserves cell viability, employs intrinsic properties of cells, is contact-free, and provides high-yield for the downstream analysis of the cells [17]. Yildizhan et al. proposed a PDMS chip with $3 \mathrm{D}$ carbon electrodes for the separation of monocyte cells. The work introduced the integration of 3D electrodes based on carbonization of SU8 by pyrolysis and the utilization of lower electrical impulses due to the conductivity of the carbon-based electrodes. The device demonstrated the DEP separation of live and dead human U937 monocyte cells from a mixture of cell suspension [17]. Another device that utilized DEP as a sorting technique was proposed by Hung et al. in which a device combined droplet microfluidics and DEP. The authors reported the formation of droplets and encapsulation of particles of interest. The following DEP sorting and manipulation of droplets were achieved based on the dielectrical charges of the encapsulated materials [18]. Another work that utilized modified electrodes was demonstrated by Nie et al. The authors used AgPDMS as the material for the integrated microelectrodes. Such design in the conducting-PDMS electrodes has exploited the polymer doped with Ag to enable the DEP-based bidirectional cell sliding and sorting by mirroring the unidirectional track to incorporate more parallel flow streams [19]. Hosseini et al. proposed a different DEP-based sorting device in which optimized conditions were developed based on cell stretching and lumped mechanical modeling. The authors showed how an optimized electrode design can highly increase the sorting of different cell types in a single fluid. The study proposed a model for cell elongation and verified the experimental results. The model was examined for three kinds of circulating cells, namely, erythrocyte, PBMC, and breast cancer cell line (T-47D). Although the authors utilized regular $\mathrm{Au} / \mathrm{Ti}$ electrodes as the base for the DEP device, the optimized geometry of the structures paired with a SU8 insulator layer in a PDMS channel provided label-free analysis for a large variety of cells with different sizes and properties [20].

\section{BioMEMS in Cell Separation}

Cell separation refers to the process of splitting a specific cell population from others within a biological sample, for instance, circulating tumor cells (CTCs) from blood or a particular tissue. This process is fundamental to acquire analytes of interest within a single fluid [4]. Multiple systems can be used in order to achieve the separation of different cell populations. In BioMEMS, different transport processes can be performed in microfluidic devices; hence, a number of microfluidic features are used for fluid transfer for the specific purpose of cell separation [21]. Similar to cell sorting, developed approaches for sell separation highly rely on intrinsic properties of the target cells including size, shape, charge, and deformability. In Table 2, we provide some of the latest techniques developed for cell separation within BioMEMS.

Several Lab-on-a-Chip (LOC) devices have been utilized in order to separate cells or particles based on their size. A device for size-based separation was reported in 2013 by Geislinger and Franke. The separation process benefited from hydrodynamic effects on Reynolds number (Re) to divide the cells based on their size and deformability (Table 2). The microfluidic was reported to be a suitable candidate for sorting CTCs from a mixture including red blood cells (RBCs) [22]. The authors reported possible applications of this device in cancer diagnostics and therapeutics. Moreover, Hvichia et al. described a microscale separation platform that consisted of a stepped physical structure that decreased progressively in the dimensions of the fluidic path through which the cells traveled. This process allowed capturing viable CTCs [23]. The application of microfluidics for cell separation in liquid biopsies is also a prominent and recurrent theme in deformability-based cell separation (Figure 2). In particular, CTCs have a deformability characteristic which is a key indicator for metastasis and noninvasive diagnosis of cancer [23].

Charge-based cell separation techniques employ the electrical properties of cells and/or the medium that contains them in order to cause a displacement [6]. This approach is especially useful to sort out and separate target cells from a homogeneous solution since low concentrations and similarities in shape and size can make this task difficult [24]. Song et al. proposed an array of oblique interdigitated gold electrodes within a PDMS-based BioMEMS for the continuous sorting of stem cells in a homogeneous mixture of cells (Table 2). This facilitated further applications of this device in differentiation of target cells and cell-cell studies [25]. These technologies enable scientists to generate new diagnostic tools that could considerably shorten the time needed for bioanalytical assays.

Another technology that has been used for cell separation in BioMEMS is inertial microfluidics. In inertial microfluidic devices, cells can be manipulated and separated by using hydrodynamic forces of the carrier fluid in the channel to focus particles in certain bands. This passive manipulation relies on the microchannel characteristics and the intrinsic hydrodynamic effects of the target cells [26]. By using polyvinyl chloride (PVC), Zhu et al. described a polymer-film inertial microfluidic jigsaw (PIMJ) sorter for rare cell separation. The proposed device was fabricated by assembling laserpatterned polymer-film layers of different thicknesses and assembling it as a jigsaw puzzle. A high recovery ratio of more than $90 \%$ was achieved for the separation of rare tumor cells from white blood cells (WBCs) [26].One of the main advantages of this system was the easy fabrication method, as opposed to conventional PDMS-based microchips. The authors highlighted the ease of fabrication by simple assembly of multiple layers to form a 3D structure on the same plane, enabling a faster production of devices with complex geometries without the need of a clean room facility. Razavi et al. described an inertial microfluidic device based on 3D printing with a right-angled triangular cross-section. Made from poly(methyl methacrylate) (PMMA), the device was 
TABLE 2: Recent BioMEMS platforms for cell separation including the type of the platform, the main components, the fabrication strategy, the mechanism of operation, and the specifics of each platform.

\begin{tabular}{|c|c|c|c|c|c|}
\hline BioMEMS platform & Main components & $\begin{array}{c}\text { Fabrication } \\
\text { strategy }\end{array}$ & Mechanism of operation & Specifics & Ref. \\
\hline $\begin{array}{l}\text { Noninertial } \\
\text { hydrodynamic lift- } \\
\text { induced cell sorting } \\
\text { device }\end{array}$ & $\begin{array}{l}\text { Syringe pumps } \\
\text { Microfluidic chip } \\
\text { Voltage source }\end{array}$ & & $\begin{array}{l}\text { The separation process took } \\
\text { advantage of size and } \\
\text { deformability as intrinsic } \\
\text { biomarkers were induced by a } \\
\text { hydrodynamic effect at very low } \\
\text { Re, separating the target cells by } \\
\text { their size. }\end{array}$ & $\begin{array}{l}\text { The device is capable of sorting } \\
\text { MV3-melanoma cells from an } \\
\text { RBC suspension at a high } \\
\text { hematocrit level. } \\
\text { The mechanism of sorting is } \\
\text { gentle compared to other label- } \\
\text { free techniques. }\end{array}$ & {$[22]$} \\
\hline $\begin{array}{l}\text { Parsortix }{ }^{\mathrm{TM}} \text { system } \\
\text { for cell capture }\end{array}$ & $\begin{array}{l}\text { Plastic molding } \\
\text { containing a } \\
\text { stepped separation } \\
\text { structure and } \\
\text { microchannels } \\
\text { Heat-bonded thin } \\
\text { plastic cover }\end{array}$ & $\begin{array}{l}\text { Standard soft } \\
\text { lithography }\end{array}$ & $\begin{array}{l}\text { The system used a microfluidic } \\
\text { cassette that captured cells based } \\
\text { on their size and deformability. } \\
\text { The sample passes through a } \\
\text { fluidic path leading to flow } \\
\text { distribution channels and over the } \\
\text { stepped separator. }\end{array}$ & $\begin{array}{l}\text { Cell size must be known for the } \\
\text { system to be able to capture them. } \\
\text { The device does not depend on } \\
\text { antibody affinity. }\end{array}$ & {$[23]$} \\
\hline $\begin{array}{l}\text { Continuous-flow } \\
\text { microfluidic DEP } \\
\text { chip }\end{array}$ & $\begin{array}{l}\text { Oblique } \\
\text { interdigitated } \\
\text { electrode array } \\
\text { AC frequency } \\
\text { generator } \\
\text { Syringe pumps } \\
\text { Microfluidic chip }\end{array}$ & & $\begin{array}{l}\text { The devices used DEP to force the } \\
\text { target cells to flow in a determined } \\
\text { path. }\end{array}$ & $\begin{array}{c}\text { The device facilitated the } \\
\text { continuous label-free cell } \\
\text { separation. }\end{array}$ & {$[25]$} \\
\hline $\begin{array}{l}\text { Paper-based } \\
\text { extraction device }\end{array}$ & $\begin{array}{l}\text { Paper-based valve } \\
\text { Sponge-based } \\
\text { buffer storage }\end{array}$ & $\begin{array}{l}\text { 3D printing using } \\
\text { a photopolymer } \\
\text { resin }\end{array}$ & $\begin{array}{l}\text { Separation was achieved by the } \\
\text { combination of high affinity } \\
\text { between the negatively charged } \\
\text { particles of interest and the } \\
\text { positively charged glass fiber. }\end{array}$ & $\begin{array}{l}\text { The device can be used in } \\
\text { resource-limited settings. }\end{array}$ & [87] \\
\hline $\begin{array}{l}\text { Microfluidic chip } \\
\text { with a ratchet } \\
\text { mechanism coupled } \\
\text { with a hydrodynamic } \\
\text { concentrator }\end{array}$ & $\begin{array}{l}\text { 2D microscale } \\
\text { funnel membrane- } \\
\text { based } \\
\text { Microvalves }\end{array}$ & $\begin{array}{l}\text { Standard PDMS } \\
\text { multilayer soft } \\
\text { lithography } \\
\text { fabrication } \\
\text { techniques }\end{array}$ & $\begin{array}{l}\text { The device used oscillatory flow to } \\
\text { manipulate cancer cells and } \\
\text { leukocytes and performed a } \\
\text { throughput separation. }\end{array}$ & $\begin{array}{l}\text { The device has the ability to } \\
\text { refresh the filter microstructure } \\
\text { after each separation. }\end{array}$ & {$[88]$} \\
\hline Inertial focusing LOC & $\begin{array}{l}\text { Rectangular } \\
\text { microchannel } \\
\text { Serpentine } \\
\text { microchannels } \\
\text { Fluidic resistors }\end{array}$ & & $\begin{array}{l}\text { The device operated a high- } \\
\text { throughput separation by } \\
\text { multichannel shape-based sorting } \\
\text { of the microalga using inertial } \\
\text { focusing techniques. }\end{array}$ & $\begin{array}{l}\text { The device is cost-effective and } \\
\text { label-free. }\end{array}$ & [95] \\
\hline $\begin{array}{l}\text { Elasto-inertial } \\
\text { pinched flow } \\
\text { fractionation } \\
\text { microfluidic platform }\end{array}$ & $\begin{array}{l}\text { Asymmetric T- } \\
\text { shaped } \\
\text { microchannels } \\
\text { Syringe pumps }\end{array}$ & $\begin{array}{l}\text { Standard soft } \\
\text { lithography } \\
\text { techniques with } \\
\text { PDMS }\end{array}$ & $\begin{array}{l}\text { Continuous separation of } \\
\text { particles of equal volume by } \\
\text { exploiting the elasto-inertial lift- } \\
\text { induced particle viscoelastic } \\
\text { fluids. The device uses particle's } \\
\text { rotational movements controlled } \\
\text { by the zig-zag shape of the } \\
\text { induced microchannel. }\end{array}$ & $\begin{array}{l}\text { The device offered a label-free } \\
\text { separation. }\end{array}$ & {$[96]$} \\
\hline $\begin{array}{l}\text { Polymer-film inertial } \\
\text { microfluidic jigsaw } \\
\text { sorter }\end{array}$ & $\begin{array}{l}\text { A trapezoidal } \\
\text { spiral inertial } \\
\text { microfluidic sorter } \\
\text { chip } \\
\text { Syringe pump }\end{array}$ & $\begin{array}{l}\text { Laser cutting } \\
\text { Plasma-activated } \\
\text { bonding }\end{array}$ & $\begin{array}{l}\text { The device utilized a syringe } \\
\text { pump to inject the cell suspension } \\
\text { at specific flow rates. The cells } \\
\text { were separated by inertial forces } \\
\text { and recovered in different outlets. }\end{array}$ & $\begin{array}{l}\text { The device demonstrates a } \\
\text { complete separation of the binary } \\
\text { particles with a minimum size } \\
\text { difference of } 2 \mu \mathrm{m} \text {. The device was } \\
\text { successfully applied for the } \\
\text { separation of rare CTCs from the } \\
\text { blood samples. }\end{array}$ & {$[26]$} \\
\hline $\begin{array}{l}\text { 3D printed inertial } \\
\text { microfluidic device }\end{array}$ & $\begin{array}{l}\text { 3D printed device } \\
\text { PMMA sheet } \\
\text { Syringe pump }\end{array}$ & $\begin{array}{l}\text { DLP 3D printing } \\
\text { Pressure- } \\
\text { sensitive adhesive } \\
\text { bonding }\end{array}$ & $\begin{array}{c}\text { The device utilized the inertial } \\
\text { forces to separate different cell } \\
\text { lines. }\end{array}$ & $\begin{array}{l}\text { Through this strategy, fabrication } \\
\text { of a right-angled triangular cross- } \\
\text { section was possible. }\end{array}$ & {$[27]$} \\
\hline
\end{tabular}


TABLE 2: Continued.

\begin{tabular}{|c|c|c|c|c|c|}
\hline BioMEMS platform & Main components & $\begin{array}{c}\text { Fabrication } \\
\text { strategy }\end{array}$ & Mechanism of operation & Specifics & Ref. \\
\hline $\begin{array}{l}\text { Acoustofluidic chip } \\
\text { for } \\
\text { nano/microparticle } \\
\text { separation }\end{array}$ & $\begin{array}{l}\text { PDMS-based chip } \\
\text { SAW transducer } \\
\text { Function } \\
\text { generator } \\
\text { Amplifier Syringe } \\
\text { pump }\end{array}$ & $\begin{array}{l}\text { Photolithography } \\
\text { Standard soft } \\
\text { lithography } \\
\text { techniques with } \\
\text { PDMS }\end{array}$ & $\begin{array}{l}\text { Hydrodynamic focusing was } \\
\text { applied allowing particles to enter } \\
\text { consistently into the same } \\
\text { position in the acoustic field, and } \\
\text { once the SAW field was applied, } \\
\text { particles were deflected and } \\
\text { separated into different streams. }\end{array}$ & $\begin{array}{l}\text { Particles with a wide size range } \\
\text { from } 200 \mathrm{~nm} \text { to } 10 \mu \mathrm{m} \text { can be } \\
\text { separated with this device. }\end{array}$ & [28] \\
\hline
\end{tabular}

CTCs: circulating tumor cells; DEP: dielectrophoresis; DLP: digital light processing; LOC: Lab-on-a-Chip; PDMS: polydimethyl siloxane; PMMA: poly(methyl methacrylate); RBCs: red blood cells; Re: Reynolds number; SAW: surface acoustic wave ; 3D: three-dimensional; 2D: two-dimensional.

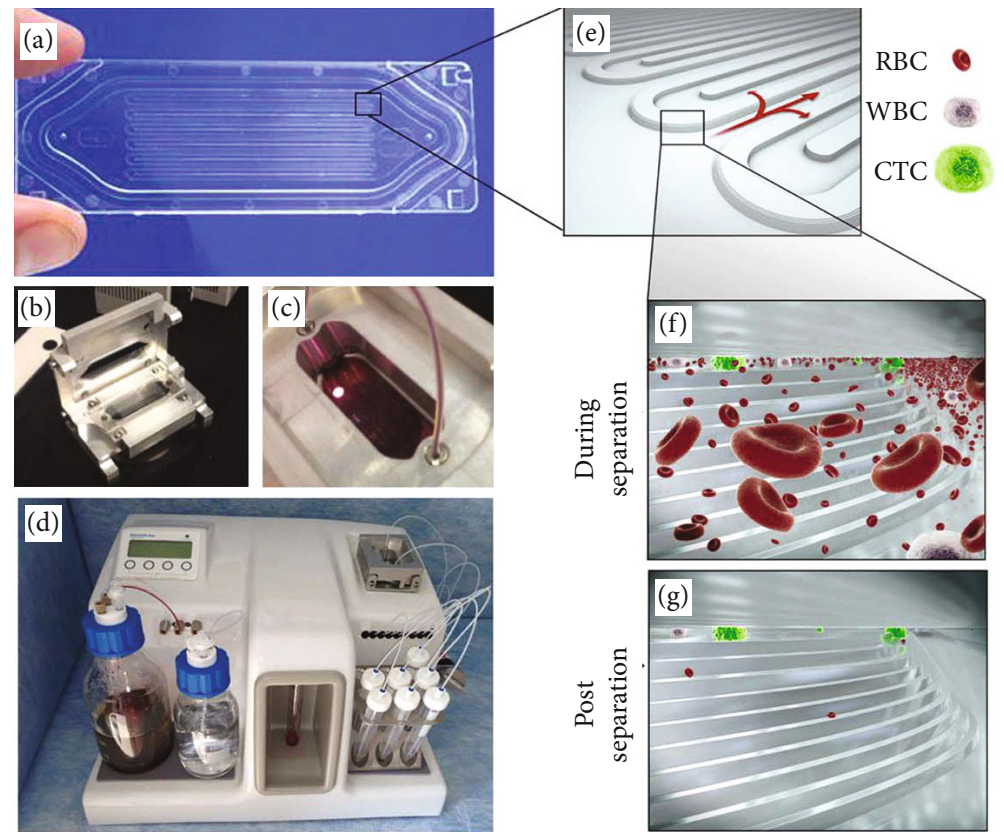

FIgURE 2: The microfluidic device for the (a-g) cell capture process shows the device and the progression of capturing CTCs [23], (02016, National Library of Medicine.

capable of separating target cells without altering the cell activity which made it a safe method for biological assays [27]. Alike the work of Zhu et al., the authors also described the challenges of manufacturing PDMS-based devices and the new possibilities that alternative polymers could give to the BioMEMS devices.

As previously discussed in the cell sorting section, SAW is a technique often utilized in BioMEMS devices. Zhao et al. described a disposable PDMS acoustofluidic chip for nano/microparticle separation [28]. The authors demonstrated the use of a hybrid channel design with hard and soft materials and tilted-angle standing SAWs. The disposable part of the device was the PDMS-based chip with the channels, while the interdigital transducers (IDTs) were reused multiple times. The device was capable of differentiating and successfully separating bacteria from RBCs with a purity of $96 \%$. The hybrid hard/soft PDMS channels were employed to minimize the acoustic attenuation factor that PDMS causes in SAW. This control was achieved by utilizing a low thickness PDMS bottom enclosure [28].

\section{BioMEMS in Cell Isolation/Trapping}

In molecular and cellular biology research, cell isolation and trapping are essential steps for accurate and precise analysis of specific cell types which subsequently allow exploiting particular cell properties and cell categorization [29]. Highly efficient cell isolation and trapping could open various windows of opportunity to the areas of drug discovery, cancer genomics, cell separation, confinement, and controllable transfection of cells [30]. Table 3 provides an overview of the latest advancements made over the past five years highlighting the specific interface between BioMEMS and cell isolation/trapping.

Centrifugation enables fluids with different densities to sediment into layers of increasing density under the influence of gravitational forces [29]. Espulgar et al. proposed a PDMSbased centrifugal microfluidic device to trap single cells with controlled separation distance allowing studying of cell growth, coupling, decoupling, and beating in a rapid manner [31]. Other examples of PDMS cell trapping device include 
TABLE 3: Recent BioMEMS platforms for cell isolation/trapping including the type of the platform, the main components, the fabrication strategy, the mechanism of operation, and the specifics of each platform.

\begin{tabular}{|c|c|c|c|c|c|}
\hline $\begin{array}{l}\text { BioMEMS } \\
\text { platform }\end{array}$ & Main components & Fabrication strategy & Mechanism of operation & Specifics & Ref. \\
\hline $\begin{array}{l}\text { Centrifugal } \\
\text { microfluidic } \\
\text { chip }\end{array}$ & $\begin{array}{l}\text { Microfluidic chip } \\
\text { Acrylic plastic } \\
\text { plates with silicon } \\
\text { tubes } \\
\text { Filtering channels } \\
\text { Focusing channels } \\
\text { Trapping channels }\end{array}$ & Lithography methods & $\begin{array}{l}\text { The device applied centrifugal } \\
\text { force to isolate the cells. }\end{array}$ & $\begin{array}{l}\text { The device does not need large } \\
\text { equipment for cell manipulation. }\end{array}$ & {$[31]$} \\
\hline $\begin{array}{l}\text { Planar p-DEP } \\
\text { chip }\end{array}$ & $\begin{array}{l}\text { P-DEP chip } \\
\text { TPIDA electrodes } \\
\text { (A-IDA and B- } \\
\text { IDA electrodes) } \\
\text { Microfluidic } \\
\text { channels } \\
\text { Microwell array }\end{array}$ & $\begin{array}{l}\text { Standard } \\
\text { photolithography } \\
\text { technique }\end{array}$ & $\begin{array}{l}\text { Cells were trapped by applying AC } \\
\text { signal into the electrodes. The } \\
\text { paired cells in each microwell } \\
\text { could be pushed together into a U- } \\
\text { shaped microbaffle by liquid flow } \\
\text { through a capillary-sized channel, } \\
\text { resulting in single isolation and } \\
\text { subsequent cell-cell contact. }\end{array}$ & The device is facile and accurate. & {$[32]$} \\
\hline $\begin{array}{l}\text { 3D cell rotation } \\
\text { BioMEMS } \\
\text { platform }\end{array}$ & $\begin{array}{l}\text { V-shaped pillars } \\
\text { Microchannels } \\
\text { C-PDMS } \\
\text { electrodes } \\
\text { ITO electrode } \\
\text { Controllable 3D } \\
\text { cell rotation }\end{array}$ & $\begin{array}{l}\text { Photolithography and } \\
\text { wet etching methods }\end{array}$ & $\begin{array}{l}\text { Cell medium would be streamed } \\
\text { along with the flow, and only one } \\
\text { cell was trapped at the opening of } \\
\text { the V-shaped pillars, subsequently } \\
\text { back-flowed, and stabilized inside } \\
\text { the chamber. }\end{array}$ & $\begin{array}{l}\text { The strategy offered a low-cost } \\
\text { device with straightforward } \\
\text { approach that had a better control } \\
\text { over cell trapping and isolation. }\end{array}$ & {$[34]$} \\
\hline $\begin{array}{l}\text { Flow-through } \\
\text { LOC }\end{array}$ & $\begin{array}{l}\text { Gold electrodes } \\
\text { PDMS } \\
\text { microfluidic } \\
\text { channel } \\
\text { DEP trap }\end{array}$ & $\begin{array}{c}\text { Standard } \\
\text { photolithography and } \\
\text { lift-off techniques }\end{array}$ & $\begin{array}{l}\text { Cells were trapped at the constant } \\
\text { flow with the continuous } \\
\text { application of the electric field. } \\
\text { The n-DEP allowed trapping the } \\
\text { cells independent of gravity. }\end{array}$ & $\begin{array}{l}\text { The device offered control over } \\
\text { unwanted lysis. It involved } \\
\text { simultaneous n-DEP trapping } \\
\text { and AC electroporation. }\end{array}$ & {$[30]$} \\
\hline $\begin{array}{l}\text { Microfluidic cell } \\
\text { trap array }\end{array}$ & $\begin{array}{l}\text { Microfluidic } \\
\text { channel } \\
\text { Hydrodynamic } \\
\text { sieve-like trap } \\
\text { system }\end{array}$ & $\begin{array}{l}\text { Photolithography } \\
\text { technique }\end{array}$ & $\begin{array}{l}\text { The cells were flowed in, and } \\
\text { single cells were trapped on the } \\
\text { protein micropatterns by the } \\
\text { sieve-like traps. }\end{array}$ & $\begin{array}{c}\text { The device used passive trapping } \\
\text { suitable for preserving cell } \\
\text { viability. }\end{array}$ & {$[35]$} \\
\hline $\begin{array}{l}\text { Microfluidic } \\
\text { device with } \\
\text { integrated } \\
\text { pipettes }\end{array}$ & $\begin{array}{l}\text { Microfluidic } \\
\text { network of } 60 \\
\text { loops } \\
\text { Bypass channel } \\
\text { Cavities } \\
\text { Trap } \\
\text { Pipettes }\end{array}$ & $\begin{array}{l}\text { Soft lithography } \\
\text { process }\end{array}$ & $\begin{array}{l}\text { The cell-drug mixture was injected } \\
\text { into the grid, and the device } \\
\text { trapped individual cells within the } \\
\text { array of cavities and immobilized } \\
\text { them. }\end{array}$ & $\begin{array}{l}\text { The devices presented control } \\
\text { over the distribution of } \\
\text { cells/clusters. It involves a } \\
\text { downstream assay for capturing } \\
\text { rare CTCs. }\end{array}$ & {$[36]$} \\
\hline $\begin{array}{l}\text { Microfluidic } \\
\text { device }\end{array}$ & $\begin{array}{l}\text { Syringe pump } \\
\text { Magnetic stirring } \\
\text { bar } \\
\text { Micropillar array } \\
\text { Fluorescence } \\
\text { microscope }\end{array}$ & $\begin{array}{l}\text { Photolithography and } \\
\text { soft lithography } \\
\text { techniques }\end{array}$ & $\begin{array}{l}\text { The cells were kept in suspension } \\
\text { through a magnetic stirring bar, } \\
\text { while the cell mixture or blood } \\
\text { sample was pumped through the } \\
\text { device. }\end{array}$ & $\begin{array}{l}\text { It is a noninvasive device for } \\
\text { monitoring the response to cancer } \\
\text { treatments. }\end{array}$ & [37] \\
\hline $\begin{array}{l}1 \mathrm{D} \text { cell } \\
\text { migratory assay }\end{array}$ & $\begin{array}{l}\text { Hydrodynamic } \\
\text { trap microfluidic } \\
\text { channels } \\
\text { Microtracks } \\
\text { Stamped } \\
\text { substrates } \\
\text { Laser ablated } \\
\text { substrates }\end{array}$ & $\begin{array}{c}\text { Multilayer } \\
\text { photolithography } \\
\text { process }\end{array}$ & $\begin{array}{c}\text { Cells were seeded at low flow rate } \\
\text { onto the patterned microtracks } \\
\text { and trapped by hydrodynamic } \\
\text { barriers. }\end{array}$ & $\begin{array}{l}\text { Microtracks allowed guiding cell } \\
\text { migration with high predictability } \\
\text { and precise positioning. }\end{array}$ & [38] \\
\hline
\end{tabular}


TABLE 3: Continued.

\begin{tabular}{|c|c|c|c|c|c|}
\hline $\begin{array}{l}\text { BioMEMS } \\
\text { platform }\end{array}$ & Main components & Fabrication strategy & Mechanism of operation & Specifics & Ref. \\
\hline $\begin{array}{l}\text { Semiautomated } \\
\text { microfluidic } \\
\text { cell-based } \\
\text { biosensor }\end{array}$ & $\begin{array}{l}\text { Fluid channels } \\
\text { Pneumatic valves } \\
\text { Fluid crossed- } \\
\text { channel structure } \\
\text { Control channels }\end{array}$ & $\begin{array}{l}\text { Rapid prototyping } \\
\text { technique }\end{array}$ & $\begin{array}{l}\text { A controllable pneumatic trap was } \\
\text { used to encapsulate and discharge } \\
\text { suspended cells. }\end{array}$ & $\begin{array}{l}\text { In this device, the chemical } \\
\text { stimulation to cell was achieved } \\
\text { by flexible hydrodynamic gating. }\end{array}$ & [39] \\
\hline $\begin{array}{l}\text { Hydrodynamic } \\
\text { Snaring Array }\end{array}$ & $\begin{array}{l}\mathrm{V} \text {-shaped weirs } \\
\mathrm{U} \text {-shape dwelling } \\
\text { region } \\
\text { Microcultivation } \\
\text { system } \\
\text { 96-well plates }\end{array}$ & $\begin{array}{l}\text { Microelectrochemical } \\
\text { process, inductively } \\
\text { coupled plasma } \\
\text { etching, and } \\
\text { photolithography }\end{array}$ & $\begin{array}{l}\text { Single cells were trapped and } \\
\text { manipulated within a high flow } \\
\text { and low-pressure area that } \\
\text { reconcentrated the streamline via } \\
\text { a V-shaped weir that loaded the } \\
\text { cells, pushing them precisely into } \\
\text { the dwelling region due to the void } \\
\text { and wedge structures. }\end{array}$ & $\begin{array}{l}\text { The device is capable of trapping } \\
\text { single cells in } 10 \text { s. Additionally, it } \\
\text { allows for long-term cultivation. }\end{array}$ & {$[40]$} \\
\hline $\begin{array}{l}\text { Porous- } \\
\text { microwell } \\
\text { trapping- } \\
\text { system }\end{array}$ & $\begin{array}{l}\text { Sieved microwell } \\
\text { array } \\
\text { Microfluidic two- } \\
\text { layered channel }\end{array}$ & $\begin{array}{l}\text { Slit channel } \\
\text { lithography }\end{array}$ & $\begin{array}{l}\text { Particles were directed along the } \\
\text { top channel and captured in the } \\
\text { microwells. A shielding flow along } \\
\text { the sides of the top channel was } \\
\text { used to guide the flow directly over } \\
\text { the wells, and untrapped particles } \\
\text { were sieved along the flow path. }\end{array}$ & $\begin{array}{l}\text { In this device, well occupancy and } \\
\text { trapping were improved. }\end{array}$ & {$[41]$} \\
\hline $\begin{array}{l}\text { Polymer-based } \\
\text { porous } \\
\text { microcapsules }\end{array}$ & $\begin{array}{l}\text { Microcapsules } \\
\text { with shells and } \\
\text { asymmetrical } \\
\text { distributed funnel- } \\
\text { shaped pores }\end{array}$ & $\begin{array}{l}\text { Droplet microfluidic } \\
\text { technology and } \\
\text { chemical phase } \\
\text { separation process }\end{array}$ & $\begin{array}{l}\text { The pores' geometry and bacteria's } \\
\text { motility drive the bacteria to enter } \\
\text { the microcapsule cavity. }\end{array}$ & $\begin{array}{l}\text { The surrounding liquid } \\
\text { environment safeguards the } \\
\text { bacteria while adding bactericide } \\
\text { into the cavities greatly enhanced } \\
\text { the efficiency of the system. }\end{array}$ & {$[42]$} \\
\hline
\end{tabular}

AC: alternating current; C-PDMS: carbon-black-PDMS; CTCs: circulating tumor cells; DUV: deep ultraviolet illumination; DLD: deterministic lateral displacement; Au: gold; ITO: indium tin oxide; IDA: interdigitated array; LOC: Lab-on-a-chip; n-DEP: negative dielectrophoresis; C4F8: octafluorocyclobutane; PDMS: polydimethyl siloxane; PolyMUMP: polysilicon multiuser surface micromachining process; p-DEP: positive dielectrophoresis; Ti: titanium; TPIDA: two-pair interdigitated array.

DEP, a versatile method for cell manipulation due to its compatibility with cells, label-free nature, simplicity, and integration of in situ cell measurements [32]. DEP enables the manipulation of individual living cells by regulating electrical signals applied to the electrodes [33]. Different designs and electrode arrangements were reported for such devices. Among these proposed strategies, positive dielectrophoresis (p-DEP) offers a facile method for cell trapping which can be further used for cell communications and a precise cell pairing in cell fusion [32]. Negative dielectrophoresis (nDEP) provides a better control over unwanted lysis and simultaneous analysis of alternate current (AC) electroporation of single cells (Figure 3) [30]. Moreover, a coupling of different techniques such as hydrodynamics and DEP enables single-cell loading, cell rotation, and consequently sell isolation [34].

Another simple yet effective example of polymer-based BioMEMS was proposed by Lin et al. for accurate and controlled isolation of single cells on protein micropatterns. This PDMS microfluidic device incorporated aligning sieve-like trap arrays in a microfluidic channel to control the type, the amount, and the arrangement of nearby cells [35] (Table 3). Bithi and Vanapalli presented a pipette-based microfluidic cell isolation (MCI) device for operating single-cell drug assays. The PDMS device was developed for handling and manipulating rare types of cells and to com- partmentalize such cell samples [36]. Another example was a PDMS microfluidic device that immobilized tumor cells on the surface of the microchannels by the aim of capture agents. Functionalized with aptamer-antibody, the microchannel of this device promoted a strong bond between the substrate and the cells which allowed isolation (Table 3) [37]. Hisey et al. proposed a BioMEMS that hydrodynamically seeded single cancer cells onto polystyrene (PS) microtracks benefiting from topographical cues and encouraging migratory cell behavior. The device improved the reproducibility of cell trapping and enhanced the clinical applicability of in vitro single-cell migration assays. This device benefited from automatic analysis of single-cell migration behavior to predict treatment outcomes and antimetastasis drug screening [38]. In another study, a multiarray microchip developed by Huang et al. allowed studying mechanically induced physiological changes in cells through a side-stretching mechanism and a controllable pneumatic trap which were used to encapsulate and discharge suspended cells (Table 3). This PDMS device has shown promises in molecular processes and tissue reshaping applications [39].

Chiang et al. were able to trap a single cell in $10 \mathrm{~s}$ with a hydrodynamic snaring array (Table 3), enabling a stable perfusion culture microenvironment. Furthermore, the authors presented a unique microstructural design method. Their particular approach of V-blocking and voids enabled new 


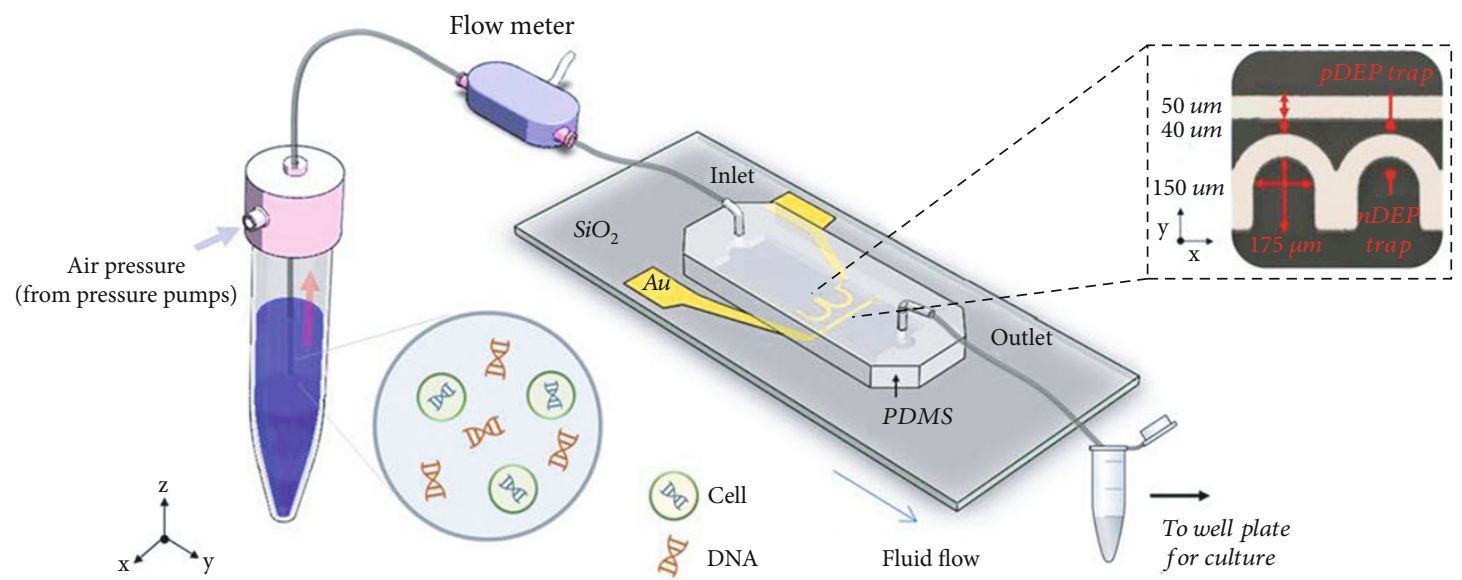

(a)

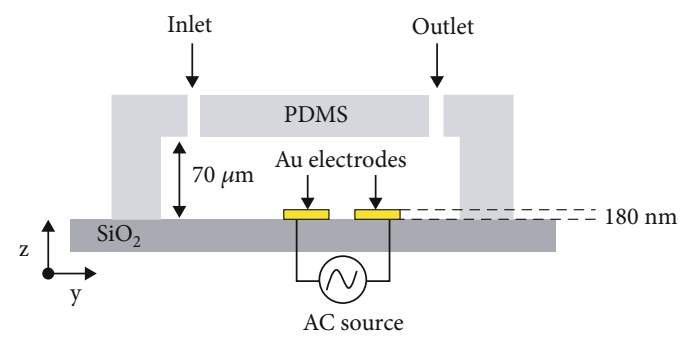

(b)

Figure 3: (a) An overview of the BioMEMS platform made from PDMS and gold electrodes and (b) a cross-section view of the trapping chamber [30], (2019, Nature Publishing Group.

techniques to trap various cell types and different cell sizes. Additionally, the authors demonstrated an independent cultural environment in each PDMS well, showing great promise for interaction studies among single and multiple cells [40]. Other studies have also benefited from hydrodynamic forces. Romita et al. have utilized hydrodynamic forces as a main driving force to capture cells and to exclude the need for sedimentation time. The authors developed sieved microwells with open pores at the bottom, enabling crossflow trapping within a double-layered PDMS microfluidic device, in a simple two-step fabrication process, as seen in Table 3. This device opened new channels to improve capture ability and well occupancy, showing great promise for single-cell analysis. Moreover, its versatile fabrication methods allowed the device to be adaptable into a wide range of sizes and shapes [41]. Scientists use various geometric designs to isolate cells in devices. For instance, in the case of Luo et al. the authors developed polymer-based porous microcapsules to capture, trap, and isolate bacteria (Table 3). In this study, poly(DL-lactide-coglycolide) (PLGA) and poly(L-lactide)b-poly(ethylene glycol) (PLA-b-PEG) were sued to create the microcapsules while polyvinylpyrrolidone (PVP) served as surfactant. The asymmetric porous geometry in combination with the bacteria's own motility greatly diminishes the need for nutrient source or chemical components to entice the bacteria, thus reducing bacterial toxicity to surrounding cells. This device has shown great promises as an alternative to reduce bacterial contamination in liquids for environmental studies [42].

\section{BioMEMS in Cell Pairing}

Cell pairing facilitates a better comprehension of cell-cell communication mechanisms and therefore is a key to understanding most physiological and pathological disorders of multicellular organisms. Cell pairing triggers the fusion between cells, a unique tool to combine genetic and epigenetic information of two different cell types. Since the 1960s, this methodology has been commonly used to identify transacting factors that affect gene expression and antibodyproducing hybridoma generation [43]. Cell paring has proven to be an excellent strategy for biological studies such as cell fusion and cell-cell communications. Cell pairing approaches commonly rely on initially trapping individual cells (explained in the previous section) followed by introducing the second cell type to the system which allows the two trapped cells to pair [44]. Table 4 provides an overview of the latest advancements of recent years highlighting the specific BioMEMS developed for cell pairing applications.

Li et al. demonstrated a strategy that used centrifugal force to hydrodynamically trap and pair cells for analysis over an extended period of time [44]. The method enabled a higher density of cell pairing units in a straightforward, rapid, and simple operation while remaining friendly to cells. Furthermore, the device allowed both homotypic and heterotypic cell pairing, accompanied by long-term on-chip coculture for the analysis of intercellular interactions. The BioMEMS device proposed in this study proved to be a robust tool in biological applications and a controllable 
TABLE 4: Recent BioMEMS platforms for cell pairing including the type of the platform, the main components, the fabrication strategy, the mechanism of operation, and the specifics of each platform.

\begin{tabular}{|c|c|c|c|}
\hline $\begin{array}{l}\text { BioMEMS } \\
\text { platform }\end{array}$ & $\begin{array}{c}\text { Main } \\
\text { components }\end{array}$ & Fabrication strategy & Mechanism of operation \\
\hline $\begin{array}{l}\text { Centrifugal } \\
\text { hydrodynamic } \\
\text { microfluidic } \\
\text { chip }\end{array}$ & $\begin{array}{l}\text { Cell chamber } \\
\text { array } \\
\text { Hydrodynamic- } \\
\text { assisted single- } \\
\text { cell traps }\end{array}$ & & $\begin{array}{l}\text { Individual cells were } \\
\text { hydrodynamically trapped and } \\
\text { relocated into cell chambers by } \\
\text { centrifugation of transient storage. } \\
\text { Subsequently, a second cell could be } \\
\text { captured and trapped in the } \\
\text { structure of the device. }\end{array}$ \\
\hline $\begin{array}{l}\text { Hydrodynamic } \\
\text { microfluidic } \\
\text { chip }\end{array}$ & $\begin{array}{c}\text { Hydrodynamic } \\
\text { trap } \\
\text { Oil-isolated } \\
\text { microchambers }\end{array}$ & & $\begin{array}{l}\text { Cells flowed by hydrostatic pressure, } \\
\text { and the corresponding traps were } \\
\text { occupied. Subsequently, residual } \\
\text { cells were washed away, and a } \\
\text { different cell suspension was added } \\
\text { sequentially. }\end{array}$ \\
\hline $\begin{array}{l}\text { Mechanical } \\
\text { parylene slide } \\
\text { system }\end{array}$ & $\begin{array}{c}\text { PRF } \\
\text { Tweezers } \\
\text { Glass substrate } \\
\text { SU-8 comb } \\
\text { layer } \\
\text { PDMS box } \\
\text { PDMS cover } \\
\text { Syringe pump }\end{array}$ & $\begin{array}{c}\text { Standard soft } \\
\text { lithography methods }\end{array}$ & $\begin{array}{l}\text { Tweezers were used to control the } \\
\text { trapping area, where PFR on the } \\
\text { comb layer was slide to open } \\
\text { positions and cells were trapped } \\
\text { along the PFR. Subsequently, } \\
\text { another cell could be trapped } \\
\text { through the same strategy. }\end{array}$ \\
\hline
\end{tabular}

The cells were captured in the singlecell traps by passive hydrodynamics and pipetting. Once saturation was reached, additional cells traveled through the trap with an increased flow. Thus, the second load of cells were introduced to the device and were passively transferred into the larger traps with the captured cells.

Before encapsulation, each cell type was stained with different fluorescent dyes. Afterward, emulsions were injected into the device and a refilling pump was used to withdraw droplets that did not trigger sorting. The positive droplets were collected into the chip, and trapping was monitored.

Multifunctionintegrated microfluidic device

\section{IDA electrodes Microwells lithography technique, and mold-replica modeling}

Droplet-based multifunctional microfluidic platform
Pneumatic

Standard lift-off process, soft

microvalve Droplet trap chamber Lateral bypass channels
Multilayer soft lithography using PDMS
P-DEP was applied to attract two cells into the trenches. n-DEP force was then activated to achieve cell pairing.

The array operates in a FIFO manner. The generated droplets were carried by the continuous oil phase into the FIFO storage unit and sequentially captured in the traps to form a library of immobilized droplets. After filling the trap array, selected droplets were moved to the merging chamber, where controlled droplet fusion was induced.
By this selective manipulation, the device could trap three or more single cells in one cell chamber. Moreover, the design gave more available spatial space to the cells and without chamber-chamber crosstalk.

High efficiency and single-cell accuracy were offered in this device with minimize chance of crosscontamination.

The mechanism allowed the control of the amount and order of lined-up cells; however, the cell pairing system depended on wettability of the surfaces.

Sequential trapping and pairing of cells with similar and diverse sizes were possible. In this platform, the cell fusion was achieved using biological, chemical, and physical biological, chemical, and physical stimuli.

The device mimics a niche environment enabling pairing and cell-cell interactions at the single-cell level. It does not require specific solutions for cells of different sizes.

Either electrical or chemical stimuli can be used for cell fusion allowing flexibility and multi-fusion.

The entire procedure was accomplished in several minutes. 
TABLE 4: Continued.

\begin{tabular}{|c|c|c|c|c|c|}
\hline $\begin{array}{l}\text { BioMEMS } \\
\text { platform }\end{array}$ & $\begin{array}{c}\text { Main } \\
\text { components }\end{array}$ & Fabrication strategy & Mechanism of operation & Specifics & Ref. \\
\hline $\begin{array}{l}\text { Droplet } \\
\text { microfluidic } \\
\text { platform }\end{array}$ & $\begin{array}{l}\text { Droplet } \\
\text { microfluidic } \\
\text { system } \\
\text { 3D electrodes } \\
\text { Microfluidic } \\
\text { channels } \\
\text { Droplet } \\
\text { cultivation } \\
\text { channel }\end{array}$ & $\begin{array}{c}\text { 2PP } \\
\text { microfabrication } \\
\text { Multilayer soft } \\
\text { lithography using } \\
\text { PDMS }\end{array}$ & $\begin{array}{l}\text { Vertical droplet cultivation was } \\
\text { reflowed into a planar droplet reflow } \\
\text { channel remaining tightly packed. } \\
\text { Subsequently, the train of water-in- } \\
\text { oil emulsion droplets flowed into the } \\
\text { aqueous flow, and the carrier oil was } \\
\text { cleaved into the first train of droplets } \\
\text { which generated a second water-in- } \\
\text { oil emulsion droplet, resulting in } \\
\text { their pairing. }\end{array}$ & $\begin{array}{l}\text { Droplets had the capacity to } \\
\text { encapsulate cells from a large library } \\
\text { to generate droplet libraries, while } \\
\text { the paired cells remained closely } \\
\text { connected. }\end{array}$ & [49] \\
\hline HL-Chip & $\begin{array}{l}\text { Microwell } \\
\text { platform } \\
\text { Dual-well HL- } \\
\text { Chip }\end{array}$ & Soft lithography & $\begin{array}{l}\text { Objects were precisely positioned } \\
\text { and loaded into the array and briefly } \\
\text { centrifuged until the occupancy was } \\
\text { achieved. The dual-well structure } \\
\text { contributed to pairing. }\end{array}$ & $\begin{array}{l}\text { The device permitted design arrays } \\
\text { of defined cell/object combinations } \\
\text { for different analysis and material } \\
\text { retrieval. }\end{array}$ & {$[52]$} \\
\hline
\end{tabular}

2PP: two-photon photolithography; AC: alternating current; FIFO: first-in, first-out; HL-Chip: hierarchical loading microwell chip; IDA: interdigital array (IDA); n-DEP: negative dielectrophoresis; PRF: parylene rail films; PDMS: polydimethyl siloxane; p-DEP: positive dielectrophoresis.

model for complex biological system studies which successfully handled fragile cells.

Hydrodynamic principles were also used for the development of a microfluidic chip that facilitated cell pairing in controlled environments with highly efficient trapping and pairing without the aid of external equipment. Cells, in this device, flowed by hydrostatic pressure and the corresponding traps were occupied. Subsequently, residual cells were washed away, and a different cell suspension was added sequentially in order to pair the predetermined cells. While the chance of cross-contamination was limited, the device offered a slightly low throughput [45]. Abe et al. demonstrated a cell pairing system suitable for mounting and positioning and manipulating cells by mechanically sliding a parylene rail films (PRF). Furthermore, the PDMS-based device could control the trapping sites, and by repetition, it enabled pairing multiple cells in a specific order within the device (Table 4). The proposed system could be applicable in studies of cell-cell interactions, cell fusion, and coculture aimed at drug discovery [46].

Cell pairing is essential for cell fusion, a natural process that occurs during embryogenesis and immune responses. Classic fusion methods depend on random cell pairings therefore lack control over cell-cell contacts [47]. In order to address this shortcoming, microfluidic devices of different classes were developed for controlled pairing of partner cells [47, 48]. Dura et al. developed a PDMS-based cell pairing device for sequential trapping and pairing multiple cells. This device employed passive hydrodynamics and flow-induced deformation to capture the cells (Table 4). The proposed device applied biological, chemical, and physical stimuli to pair cells of similar and diverse sizes [47]. Hu et al. presented a droplet-based microfluidic device for cell pairing based on dual-color sorting. This device was fabricated by using PDMS:SU8 with 10:1 ratio on silicon wafer. A refilling pump was incorporated in this device to withdraw droplets that did not trigger the sorting mechanism. This pairing method facil- itated unique collection and analysis of droplets with two different cells (stained with different dyes) within a robust tool for screening and manipulating cells [48].

Furthermore, Zhang et al. presented an integrated multilayer droplet microfluidic platform capable of handling a large number of droplets of different sizes, allowing to operate large-scale multistep droplet processing (Table 4). The platform had minimal error during the assays and could even handle large droplet sizes (known to be difficult to manipulate). The study presented two significant innovations: (1) the usage of curved microstructures and (2) a new droplet cleaving scheme. The first permitted consistent droplet reflows (in both planar and vertical directions), and the latter facilitated automatic droplet pairing. This strategy allowed continuous aqueous-phase flow and cleavage of the waterin-oil emulsion droplets, permitting sequential manipulation. This versatile PDMS-based device enabled droplet generation, reflow, cleaving, pairing, and cocultivation [49].

A PDMS microfluidic device for cell capturing, pairing, fusion, transfer, and culture was developed by $\mathrm{He}$ et al. [50]. The device incorporated capture wells and electrodes which operated by the aim of DEP (Figure 2). A p-DEP was applied to attract two cells into the trenches within capture wells, and a n-DEP was then activated to achieve cell pairing. When cells were fused, they were transferred for on-chip culture by flipping the device (Figure 4).

This simple-structured multifunctional device offers various cell-related operations with compatibility and flexibility [50]. Another multifunctional PDMS microfluidic platform was developed by Babahosseini et al. offering droplet generation, capture, storage, and selective merging of the target droplets. The droplets used in this study were of different sizes containing individual cells of different types and pairing of diverse ranges of cells within discrete droplets [51]. More recently, Zhou et al. were able to pair and align functionalized beads and different types of cells utilizing a hierarchical loading microwell chip (HL-Chip) (Table 4). The PDMS-based 


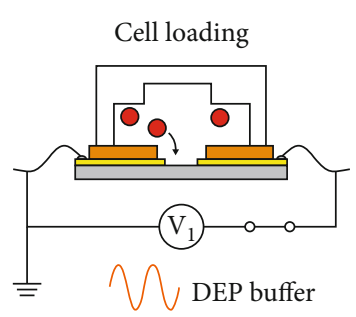

Cell fusion

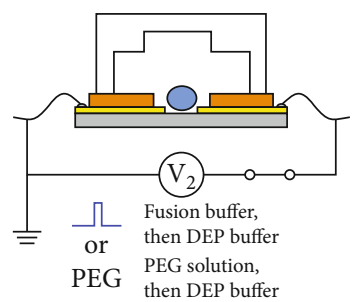

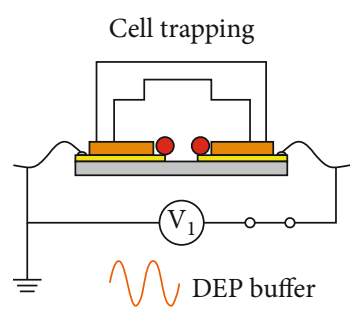

Cell transfer

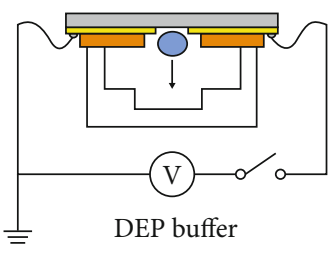

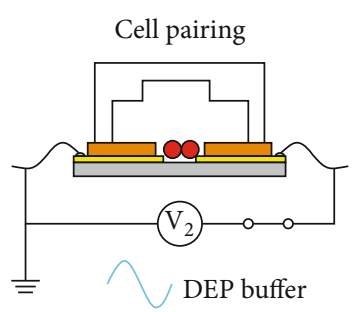

Cell culture

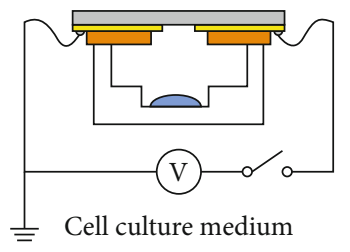

Figure 4: The schematic representation of the device and its functions in different applications. With permission [50], (O2019, American Institute of Physics.

device presented high precision and efficiency in pairing and aligning cell beads adjacent to each other. The authors claimed that the HL-Chip technology could be a powerful microtool as it enabled quantitative and simultaneous detection, retrieval of desired single cells, and high-throughput and single-cell loading efficiency whilst remaining easy to handle [52].

\section{BioMEMS in Cell-Cell Communication}

Communication between cells is of particular importance in multicellular organisms $[53,54]$. The interaction between cells regulates different processes, including cell proliferation, apoptosis, differentiation, and response to stimuli, among others. Moreover, errors in communication pathways can lead to diseases including cancer, autoimmune disorders, and diabetes [53]. Due to their complexity, cell communication mechanisms remain poorly understood. Microfluidic platforms can provide an in vivo-mimicked environment where studies of intercellular communication are performed offering advantages over other systems including a precise control of dynamic perfusion, extracellular chemical environment, cell arrangement, and single-cell manipulation [5, 8]. The results from these studies can be translated into new applications in the areas of drug screening, tissue engineering, and for understanding the nature of different diseases.

One of the main applications of BioMEMS is in studying cell-to-cell interactions between tumor cells and various types of target cells [55]. Ma et al. developed a PDMS microfluidic device that promoted indirect interactions between fibroblasts and tumor cells. The proposed platform enabled the study of the interaction between different types of cells in a single device including the interactions of human embryonic lung fibroblasts (HFL-1) with either carcinoma cells (HepG2, ACC-M, and ACC-2) or healthy epithelial cells (GES-1) (Figure 5). The results of the study revealed that the site-directed migration and transdifferentiation of embryonic fibroblasts only occur in the presence of carcinoma cells [56]. Similarly, Fang et al. created a unidirectional microfluidic chip with the same purpose of studying indirect cell interactions between either invasive or noninvasive breast cancer tumor cells (MDA-MB-231, MCF-7) and fibroblasts (MRC-5). The proposed device was made combining both soft lithography and traditional lithography techniques, and it was comprised of a PDMS piece with two culture chambers and two surrounding media channels. Both culture channels were connected by the medium transport channels, which carried the used medium of one culture chamber to its counterpart, hence enabling the unidirectional and noncontact communication between the cells. The communications between both types of tumor cells resulted in a major conversion rate from the invasive breast cancer tumor cells (MDAMB-231) [57]. Further, approaches to the study of the indirect cell interactions between cancerous and target cells include passive diffusion. Rahman et al. generated a twolayer microfluidic culture device, made from a bottom layer of agarose $(3 \%)$ and a top layer of PDMS to facilitate chemical diffusion. The culture and media supply channels were in the top PDMS layer. Breast cancer cells (MDA-MB-231) and adipose-derived stem cells (ASCs) were cultured in their respective channels, and media was supplied via their neighboring outer channels to reduce shear stress. The coculture proved to have a positive effect on MDA-MB-231 cell growth and proliferation, suggesting that ASCs provide a supportive environment for the breast cancer cells [58].

Other microdevices that are based on interconnected cell culture chambers have also been employed in cancer cell migration assays and motility studies [59] as well as chemotherapy testing applications $[60,61]$. Table 5 provides a thorough overview of some of the latest strategies developed for studying cell-cell communication.

Another important aspect that can be carefully studied in microdevices is neural development and dysfunctions [55]. Taylor et al. presented a PDMS-based device that simulated synapses on-chip, where rat hippocampal neurons were used 


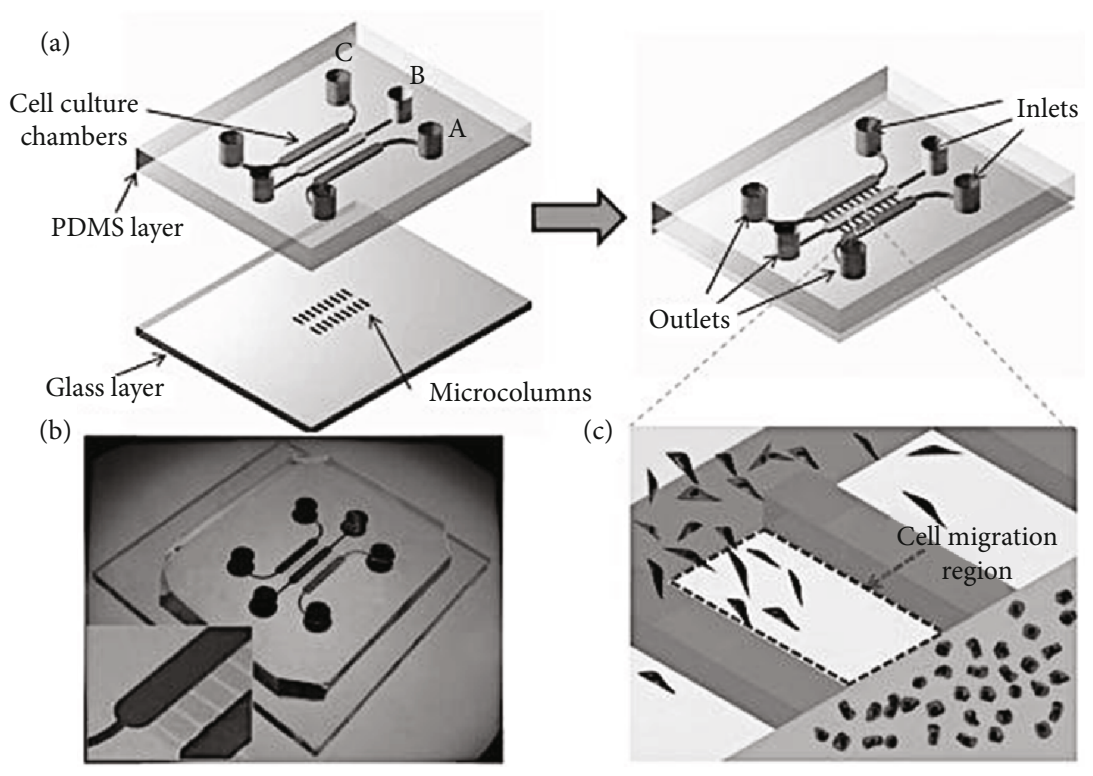

FIgURE 5: The schematic representation of the BioMEMS in direct contact with cells. With permission [56], @2010, Wiley Online Library.

to form synapses in a microarray to study the effect of chemical injuries. One significant advantage of the proposed platform was that it manipulated, both fluidically and genetically, two neuronal populations in an independent manner [62]. Schneider et al. developed a multiscale PDMS chip that permitted cell culture and cell-cell communication of neuronal progenitor cells. Their microreactor enabled cell stimulation by assembling patterned protein surfaces inside individual wells. The authors combined the use of polymer and glass substrate, to benefit from easy 3D fabrication, and chip's mountability. This device used substrates patterned with biomolecules allowing communication through narrow channels, while permitting cells to be cultured spatially separated from each other. Moreover, by this design, cells were prevented from migrating the cell soma, while permitting physical contact with neighboring cells. This microreactor showed great promise as a compartmentalized culture system. Furthermore, the experiments demonstrated that cellcell communication of physically stimulated separated cells can be feasible [63].

Other devices, such as microfluidic platforms and coculture systems, have been used to study interactions between neurons and other cells as well $[64,65]$. BioMEMSs are powerful tools for controlling and analyzing cell-cell interactions/communication at different levels of complexity. However, most of the available technologies are still at a proof-ofconcept stage. Future efforts should be made to use microfluidic chips to generate more human-like biological microenvironments.

\section{BioMEMS in Cell Differentiation and Identification}

Different BioMEMS have been developed for cell differentiation and identification. Cell differentiation is an important phenomenon that occurs numerous times in the process of multicellular formation within organisms as it alters from a simple eukaryotic cell to a more complex structure such as tissues or different cell types. Differentiation remains as one of the main functions of cells throughout tissue repair and cell turnover. The studying of cell differentiation is, therefore, vital in various biological-related fields.

For cell differentiation, Bilican et al. presented a focusingfree microfluidic device and tested the device for the differentiation of RBCs and lymphocytes. In this PDMS device, a current between the external electrodes was generated by an AC signal. In the absence of the particles, the output current was zero. In the presence of the particles, however, the positive output voltage increased. This device was capable of differentiating the target cells, even when the cells were similar size range. Additionally, the platform had the potential to be used in hematological diseases such as malaria or anemia [66]. Another PDMS device was developed by Ong et al. proposing a pump-free microfluidic platform to achieve the long-term differentiation of HepaRG cells into hepatocyte-like-cells (HLCs) and presented potential to develop in vitro liver models on a simple platform [67]. Table 6 provides a thorough overview of some of the latest strategies developed for studying cell differentiation within BioMEMS.

Alternatively, cell differentiation can be performed benefiting from the electromagnetic properties of cells. Jupe et al. developed a flexural plate-wave (FPW) sensor capable of detecting respiratory infectious viral diseases at newborns. In this strategy, an oscillation of 23 to $30 \mathrm{MHz}$ was applied to cells which caused their binding to the surface of the device. The attached cells to the surface produced a mass gain used for differentiation. The sensor was designed to be highly specific, capturing only molecules that are complementary to the target cell [68]. Gajasinghe et al. presented an electrical impedance spectroscopy-based PDMS-based device for studying tumor cells [69]. Using impedance measurement, the recorded $\Delta R_{c}$ values depended on cell size. This 
TABLE 5: Recent BioMEMS platforms for cell-cell communication including the type of the platform, the main components, the fabrication strategy, the mechanism of operation, and the specifics of each platform.

\begin{tabular}{|c|c|c|c|c|c|}
\hline BioMEMS platform & $\begin{array}{c}\text { Main } \\
\text { components }\end{array}$ & $\begin{array}{c}\text { Fabrication } \\
\text { strategy }\end{array}$ & Mechanism of operation & Specifics & Ref. \\
\hline $\begin{array}{l}\text { Microfluidic device } \\
\text { for indirect contact } \\
\text { coculture }\end{array}$ & $\begin{array}{l}\text { Two layers of } \\
\text { multiple cell } \\
\text { culture } \\
\text { chambers } \\
\text { Parallel layer of } \\
\text { migration } \\
\text { regions }\end{array}$ & $\begin{array}{l}\text { Wet etching } \\
\text { method }\end{array}$ & $\begin{array}{l}\text { Human liver carcinoma cells and } \\
\text { human embryonic lung fibroblast } \\
\text { cells were introduced into two } \\
\text { culture chambers, and culture } \\
\text { medium was infused into a third } \\
\text { chamber. }\end{array}$ & $\begin{array}{l}\text { Indirect coculture with tumor cells } \\
\text { was performed in this device. As a } \\
\text { result, direct migration and } \\
\text { transdifferentiation were observed. }\end{array}$ & {$[56]$} \\
\hline $\begin{array}{l}\text { On-chip coculture } \\
\text { system }\end{array}$ & $\begin{array}{l}\text { Center end- } \\
\text { closed channels } \\
\text { Cell culture } \\
\text { chambers } \\
\text { Microchannels }\end{array}$ & & $\begin{array}{l}\text { Melanoma cells and immune cells } \\
\text { from the spleen of wild type and } \\
\text { deficient knockout for interferon } \\
\text { regulatory factor } 8 \text { mice were } \\
\text { cocultured for one week and } \\
\text { monitored by fluorescence } \\
\text { microscopy and time-lapse } \\
\text { recordings. }\end{array}$ & $\begin{array}{l}\text { The device monitored the } \\
\text { interactions between cancer and } \\
\text { immune cells of immune } \\
\text { competence vs. } \\
\text { immunodeficiency. }\end{array}$ & {$[59]$} \\
\hline $\begin{array}{l}\text { Microfluidic device } \\
\text { for chemical and } \\
\text { physical contact }\end{array}$ & $\begin{array}{l}\text { Cell culture } \\
\text { chambers } \\
\text { Migration } \\
\text { microchannel }\end{array}$ & $\begin{array}{l}\text { Standard } \\
\text { photolithography } \\
\text { method }\end{array}$ & $\begin{array}{l}\text { Human peripheral blood } \\
\text { mononuclear cells or alternative } \\
\text { mouse splenocytes were loaded into } \\
\text { one chamber and treated and } \\
\text { untreated tumor cells into another } \\
\text { chamber. The cells were carefully } \\
\text { monitored by time-lapse recordings. }\end{array}$ & $\begin{array}{l}\text { FPR1 promoted interactions } \\
\text { between dying cancer cells and } \\
\text { leukocytes. }\end{array}$ & {$[61]$} \\
\hline $\begin{array}{l}\text { Microfluidic device } \\
\text { for tumor } \\
\text { simulation }\end{array}$ & $\begin{array}{l}\text { Cell culture } \\
\text { chambers } \\
\text { Hydrogel } \\
\text { barriers }\end{array}$ & & $\begin{array}{l}\text { Human bladder cancer cells, } \\
\text { macrophages, fibroblasts, and } \\
\text { HUVECs were cultivated inside the } \\
\text { chambers and monitored by } \\
\text { inverted microscopy. }\end{array}$ & $\begin{array}{l}\text { The device incorporated } \\
\text { simulation system for screening of } \\
\text { different chemotherapeutic agents. }\end{array}$ & {$[60]$} \\
\hline Synapses on-chip & $\begin{array}{l}\text { Microgrooves } \\
\text { Chambers } \\
\text { Perfusion } \\
\text { channel }\end{array}$ & $\begin{array}{l}\text { Soft lithography } \\
\text { method }\end{array}$ & $\begin{array}{l}\text { Rat hippocampal neurons were } \\
\text { plated in the two compartments, } \\
\text { cultured, and then infected with } \\
\text { either a GFP- or RFP-Sindbis virus } \\
\text { in order to visualize potential } \\
\text { connections. }\end{array}$ & $\begin{array}{l}\text { The device incorporated } \\
\text { simulation system to access and } \\
\text { manipulate synaptic regions. }\end{array}$ & {$[62]$} \\
\hline $\begin{array}{l}\text { Axon and glia } \\
\text { coculture system }\end{array}$ & $\begin{array}{c}\text { Two } \\
\text { compartments } \\
\text { Central channels }\end{array}$ & $\begin{array}{c}\text { Standard } \\
\text { photolithography }\end{array}$ & $\begin{array}{l}\text { Neurons and glial cells were } \\
\text { cultured in separate chambers. Only } \\
\text { neuronal processes (especially } \\
\text { axons) could enter the glial side } \\
\text { through the central channels. }\end{array}$ & $\begin{array}{c}\text { The device allowed the studying of } \\
\text { the signaling pathways between } \\
\text { neurons and glia. }\end{array}$ & {$[64]$} \\
\hline $\begin{array}{l}\text { Macro-micro-nano } \\
\text { system }\end{array}$ & $\begin{array}{l}\text { Cell-seeding } \\
\text { compartments } \\
\text { Nanochannel } \\
\text { array }\end{array}$ & $\begin{array}{c}\text { Two-step } \\
\text { photolithography } \\
\text { process }\end{array}$ & $\begin{array}{c}\text { Osteocyte-like cells and motor } \\
\text { neurons were cultured on the device } \\
\text { for } 7 \text { days and heated from one side. } \\
\text { The concentrations of extracellular } \\
\text { ATP and ATP receptor were } \\
\text { measured to quantify the response } \\
\text { of the cells. }\end{array}$ & $\begin{array}{l}\text { The device measured the signal } \\
\text { response of osteocytes and } \\
\text { neurons to heat shock. }\end{array}$ & [97] \\
\hline $\begin{array}{l}\text { Multicompartment } \\
\text { neuron-glia } \\
\text { coculture platform }\end{array}$ & $\begin{array}{l}\text { Circular soma } \\
\text { compartment } \\
\text { Satellite } \\
\text { axon/glia } \\
\text { compartments } \\
\text { Microchannels }\end{array}$ & $\begin{array}{l}\text { Micromilling, hot } \\
\text { embossing, and } \\
\text { soft lithography } \\
\text { methods }\end{array}$ & $\begin{array}{l}\text { Dissected primary neuron cells were } \\
\text { loaded into the soma compartment. } \\
\text { After 14-17 days of culture. When a } \\
\text { dense axonal layer inside the } \\
\text { axon/glia compartments was } \\
\text { formed, oligodendrocyte progenitor } \\
\text { cells and astrocytes were loaded on } \\
\text { top of the isolated axon layer. }\end{array}$ & $\begin{array}{l}\text { The device facilitated the studying } \\
\text { of the central nervous system } \\
\text { axonal biology and axon-glia } \\
\text { interactions. }\end{array}$ & {$[65]$} \\
\hline
\end{tabular}


TABle 5: Continued.

\begin{tabular}{|c|c|c|c|c|c|}
\hline BioMEMS platform & $\begin{array}{c}\text { Main } \\
\text { components }\end{array}$ & $\begin{array}{l}\text { Fabrication } \\
\text { strategy }\end{array}$ & Mechanism of operation & Specifics & Ref. \\
\hline PDMS chip & $\begin{array}{l}\text { PDMS chip } \\
\text { Microreactor } \\
100 \text { mesoscale } \\
\text { open wells } \\
\text { Microscale deep } \\
\text { channels }\end{array}$ & $\begin{array}{l}\text { Soft lithography } \\
\text { method and UV } \\
\text { lithography }\end{array}$ & $\begin{array}{l}\text { Cells were cultured in adjacent wells } \\
\text { in the microreactor. Cell-cell } \\
\text { communication was possible via the } \\
\text { interconnecting channels of } \\
\text { neighboring wells. }\end{array}$ & $\begin{array}{c}\text { The microstructure system allows } \\
\text { both spatially separated } \\
\text { cocultivation and specific } \\
\text { treatment of cells. }\end{array}$ & {$[63]$} \\
\hline $\begin{array}{l}\text { Unidirectional } \\
\text { microfluidic chip }\end{array}$ & $\begin{array}{c}\text { Two culture } \\
\text { chambers } \\
\text { Two surrounded } \\
\text { medium } \\
\text { channels }\end{array}$ & $\begin{array}{c}\text { Traditional } \\
\text { photolithography } \\
\text { and soft } \\
\text { lithography }\end{array}$ & $\begin{array}{l}\text { Cells were cultured in separate } \\
\text { culture chambers, and their } \\
\text { respective secretions traveled } \\
\text { through the medium channels to the } \\
\text { opposing culture chambers. }\end{array}$ & $\begin{array}{c}\text { The device facilitated the study of } \\
\text { communication and conversion } \\
\text { between healthy and cancerous } \\
\text { cells. }\end{array}$ & {$[57]$} \\
\hline $\begin{array}{l}\text { Two-layer } \\
\text { microfluidic device }\end{array}$ & $\begin{array}{l}\text { PDMS layer } \\
\text { Two culture } \\
\text { channels } \\
\text { Two media } \\
\text { supply channels } \\
\text { Agarose layer }\end{array}$ & $\begin{array}{l}\text { Traditional } \\
\text { photolithography, } \\
\text { soft lithography, } \\
\text { and PDMS } \\
\text { replication }\end{array}$ & $\begin{array}{l}\text { Breast cancer cells and human } \\
\text { adipose stromal cells were cultured } \\
\text { in the inner culture channels while } \\
\text { fresh media was supplied by the } \\
\text { outer channels. The spacing } \\
\text { between the media and the cell } \\
\text { channels allowed the delivery of } \\
\text { fresh media and cellular crosstalk } \\
\text { via passive diffusion. }\end{array}$ & $\begin{array}{l}\text { The delivery of fresh media via a } \\
\text { separate channel reduced the risk } \\
\text { of the cells' exposure to shear } \\
\text { stress. }\end{array}$ & {$[58]$} \\
\hline
\end{tabular}

ATP: adenosine triphosphate; FPR1: formyl peptide receptor 1; HUVECs: human umbilical vein endothelial cells; PDMS: polydimethylsiloxane.

noninvasive device had an effectiveness of $93.2 \%$ without the need for functionalization or cell labeling.

Lui et al. used the electromagnetic properties of cells to identify and count the cells in situ. In this single-cell detection sensor, three electrodes were divided the straight microchannels into two consecutive stage microcoulter. When the cells passed through the microcoulter, each cell generated voltage pulses and by using the magnetic beads, the targetcell was identified. This detection method has shown the potential to be used in drug screening and stem cell population analysis [70]. Ghassemi et al. performed the detection of CTC through impedance spectroscopy. The PDMS-based microfluidic device had two main channels for delivery and constriction. The cell suspension was inserted into the delivery channel and was subsequently sent to the constriction channel to measure the cell's impedance. Finally, this system not only differentiated normal and cancer cells with more than $90 \%$ accuracy, but also has potential to identify different types of cancer [71]. Huang et al. developed an in situ single-cell recognition system (ISCRS) in order to extract a single-adhered-cell and perform the analysis of its phosphatidylcholine (PC) compositions through mass spectrometry (MS). This methodology used the U87-MG cells (U87), human hepatoma (HepG2) cells, human epithelial colorectal adenocarcinoma (Caco-2) cells, and human umbilical vein endothelial cells (HUVEC) for the single-cell identification and classification. The single-cell probe, which is the main component for the analytical system, was fabricated from PDMS using standard soft lithography techniques. The ISCRS consisted of four steps: flow injection, observation, operation, and detection system. Once the cell's mass data was collected, the cell identification was done by the application of a linear discriminant analysis (LDA). The device has shown an accuracy rate of $91.8 \%$ for cell classification. This methodology has potential for cell identification and auxiliary disease diagnosis [72]. Zhu et al. proved that cells stained with gold nanorods (GNRs) could be detected and stimulated simultaneously due to femtosecond-laser irradiation. While the laser could cause necrosis of apoptosis, the effect could be controlled by adjusting the laser focusing. The ideal exposure duration was found to be around 1 and $2 \mathrm{~ms} / \mathrm{cell}$. This PDMS-based microfluidic device showed that photostimulation could be useful for cell detection [73].

\section{BioMEMS in Cell Culture}

Cell culture is a fundamental step in most cell-related studies. It is a process of growing and monitoring various aspects of cells in a laboratory environment. While traditional 2D cultures performed in petri dish may fail to mimic the microenvironment of cells, the 3D cell culture setups within BioMEMS present carefully controlled conditions, which are similar to those of cells' natural environment [74]. BioMEMSs for cell culture also provide controlled temperature, continuous supply of nutrients, and monitored gas exchange. Various advancements of BioMEMS in 3D cell culture have made significant contributions to the areas of in vitro disease modeling, pharmaceutical industries, drug testing, gene expression, drug toxicology, and diagnosis, among others.

As previously mentioned, a precise monitoring of culture conditions is of vital importance which, in turn, initiated development of novel strategies for 3D cell culture. These new developments cover a range of advancements from the shape of the culture chambers [75-77] to the fabrication materials $[76,78]$. The temperature, in particular, plays a great role as it should remain homogeneous across the device 
TABLE 6: Recent BioMEMS platforms for cell differentiation and identification including the type of the platform, the main components, the fabrication strategy, the mechanism of operation, and the specifics of each platform.

\begin{tabular}{lcccc}
\hline $\begin{array}{l}\text { BioMEMS } \\
\text { platform }\end{array}$ & $\begin{array}{c}\text { Main } \\
\text { components }\end{array}$ & $\begin{array}{c}\text { Fabrication } \\
\text { strategy }\end{array}$ & Mechanism of operation & Specifics \\
\hline
\end{tabular}

$\mu \mathrm{IFC} \quad \begin{array}{cc}\text { Au and } \mathrm{Cr} \\ \text { electrodes }\end{array} \quad \begin{gathered}\text { Conventional soft } \\ \text { lithography } \\ \text { technique }\end{gathered}$

A current between the external electrodes was generated by an AC signal. In the absence of particles, the output current was zero. In the presence

$\begin{array}{lc}\begin{array}{l}\text { Pump-free } \\ \text { microfluidic } \\ \text { platform }\end{array} & \begin{array}{c}\text { PDMS-based } \\ \text { microfluidic } \\ \text { device } \\ \text { Micropillars } \\ \text { Valve control }\end{array} \\ \begin{array}{lc}\text { Frequency shift- } \\ \text { based POC device }\end{array} & \text { FPW sensor } \\ & \text { Comb-like } \\ & \text { IDT electrodes }\end{array}$

Electrical impedance spectroscopybased LOC

$$
\begin{array}{cc}
\text { Silicon wafers } & \begin{array}{c}
\text { Photolithography } \\
\text { and PDMS }
\end{array} \\
& \text { etching }
\end{array}
$$

PDMS

Soft lithography and lift-off

Standard soft lithography

Photolithography and lift-off
Impedance measurementbased microfluidic device

$\begin{array}{lc}\text { Single-cell } & \text { magnet } \\ \text { Electrodes } & \text { Microcoulter } \\ \text { cotection sensor } & \text { counter } \\ \text { Microfluidic } & \text { chip }\end{array}$

PDMS

Impedance-based CTC detector

Microchannels

Bypass

channels

Coplanar

electrodes

External magnet

Microcoulter Microfluidic chip

Syringe pump Sensors Planar electrodes

PDMS

ISCRS ESI-QTOF-
Soft lithography and DRIE

Five photolithographic steps based on photomask-set MS Syringe pump

Standard soft lithography
A pump-free perfusion system was used for long-term differentiation. A passive pumping system was implemented to control medium perfusion in a constant flow rate.

Oscillations (23-30 MHz) were introduced to the device and caused the attached cells to the surface produced a mass gain.

Impedance measurements were done at $750 \mathrm{kHz}$ and $10 \mathrm{MHz}$. Since the cells were of different sizes, the detected $\Delta R_{c}$ values depended on the size of cells. Finally, opacity could be used to differentiate cell lines.

The first path in this device was a trap while the second path was a bypass channel. When the trap was empty, a cell would be driven into the trap. Once the trap was occupied by a cell, the flowthrough path would block. Therefore, the next cell would be driven into the bypass channel and enter the next available trap.

The sensor was able to detect single cells due to their magnetic properties. Three electrodes were used and divided the straight microchannels into two consecutive stage microcoulter. When the cells passed through the microcoulter, each cell generated a voltage pulse and by using the magnetic beads, the target cells were identified.

The "off-chip" device had an embedded pair of planar electrodes. The impedance was obtained in the surrounding of the medium. When the CTC was detected, an impedance peak was obtained. When the "on-chip" device detected a CTC in the constriction channel, a peak was deviated from a constant baseline. probe's adjustment. of the particle, however, the positive output voltage increased. When the particle reached the second electrode, the negative output voltage was recorded. biomolecules to bind to the surface. The

Differentiation was possible even when the cells had similar sizes.

The differentiation was achieved within 14 days. The device had a derivation efficiency of $92 \%$.

The device binds only to one type of chemokine and repels others.

This noninvasive device has an effectiveness of $93.2 \%$. The method requires no functionalization or cell labeling.

The device could monitor dynamic changes in electrical properties of individual cells over long periods of time.

The device identifies and counts cells in situ while measuring the size of each cell individually.

Differentiation was achieved with $90 \%$ of success. The system has the potential for detecting different types of cancer.

The target cell was captured due to the The accuracy of the classification 
TABLE 6: Continued.

\begin{tabular}{lcccc}
\hline $\begin{array}{l}\text { BioMEMS } \\
\text { platform }\end{array}$ & $\begin{array}{c}\text { Main } \\
\text { components }\end{array}$ & $\begin{array}{c}\text { Fabrication } \\
\text { strategy }\end{array}$ & Mechanism of operation & Specifics \\
\hline $\begin{array}{l}\text { Photostimulation- } \\
\text { based LOC }\end{array}$ & $\begin{array}{c}\text { PDMS } \\
\text { Gold } \\
\text { nanorods }\end{array}$ & $\begin{array}{c}\text { Standard soft } \\
\text { lithography } \\
\text { and photostimulation was performed. } \\
\text { Subsequently, the solution of suspended } \\
\text { cells and oil was injected into the chip, } \\
\text { and the cells created a single-cell } \\
\text { laminar flow. Lastly, the cells were } \\
\text { delivered into a petri dish for culture } \\
\text { and analysis. }\end{array}$ & $\begin{array}{c}\text { controlled by the laser focusing. } \\
\text { [73] }\end{array}$ \\
\hline
\end{tabular}

AC: alternating current; $R_{c}$ : cell's resistance; CTCs: circulating tumor cells; Cr: chromium; CMOS: complementary metal-oxide-semiconductor; DRIE: deep reactive ion etching; ESI-QTOF-MS: electrospray quadrupole time of flight mass spectrometer; FPW: flexural plate-wave; Au: gold; GNR: gold nanorods; IDT: interdigital transducer; ISCRS: in situ single-cell recognition system; LOC: Lab-on-a-chip; $\mu$ IFC: microfluidic-based impedance flow cytometer; PDMS: polydimethyl siloxane; POC: point-of-care.

for optimal growth [79]. It poses a challenge as the system may heat up and cool down faster due to its size. Numerous efforts in temperature surveillance and control techniques have been proposed and explored using microfluidic approaches. These strategies include microheaters [80], temperature sensors, and integrated incubator [81]. Mäki et al. fabricated a device for indirect temperature measurement during cell culture [81]. This PDMS-based device incorporated a proportional-integral (PI) controller and a temperature sensor plate (TSP). The PDMS device was made of two PDMS layers and a glass lid. Six culture chambers were punched on the top PDMS layer and were irreversibly merged with the bottom layer using oxygen plasma treatment. The PI control system implemented sensors to detect the temperature of the cell culture wells and to generate a response from the closed-loop temperature control system. The platform was proven to successfully control the temperature inside and outside the culture system [81].

Nutrient depletion is a common issue in small-sized cell culture platforms. Different approaches have attempted to offer better control over these key elements [82]. In general, mammalian cells require oxygen in order to grow. Therefore, the oxygen consumption rate (OCR) is yet another important parameter to measure and control in such devices [83]. Bunge et al. developed a 3D cell culture platform for longterm cell cultivation and monitoring [82]. The culture chamber was located at the center of the device surrounded by two porous hydrogel walls, which provided a constant supply of nutrients and gases from neighboring channels [82]. A $\mu$ respirometer for monitoring OCR was also proposed by the same authors [84]. The device was fabricated using a glass wafer and a silicone piece with DRIYE-etched channels. The Madin-Darby Canine Kidney cells (MDCK) were cultured inside this device, and the oxygen concentration was recorded by the aim of platinum(II)-5,10,15,20-tetrakis(2,3,4,5,6-pentafluorphenyl)-porphyrin (PtTFPP) fluorescent dye within a PS-matrix. The glass and silicon segments of the device were oxygen-impermeable. With a low drift rate, a long-term measurement of oxygen consumption was, therefore, possible [84].

Additionally, biocompatibility accounts for one of the priorities of cell culture BioMEMS. PDMS is by far the most popular material for soft lithography and fabrication of cell culture devices as it projects great biocompatibility. However, its stability and cell adhesion properties have not been described as optimal. As a replacement, Dabaghi et al. proposed the use of polydopamine (PDA) coating prior to the application of the traditional collagen coat to improve the overall cell attachment and proliferation. Two PDA coating methods were implemented including dynamic and static coating methods. In dynamic coating, the PDA solution passed through the device with a peristaltic pump versus the static coating in which the microfluidic device was filled with the PDA solution. Human bronchial epithelial cells (HBECs) were cultured in devices with both types of coating application and showed no significant differences in cell attachment [85].

Specific cell types are more challenging to culture in vitro. Stem cells are recognized to be one of the most difficult types of cells to culture in vitro since they tend to differentiate if they are not successfully kept under conditions similar to the in vivo environments. One of the solutions to this challenge is the use of microdroplets as culture chambers. Carreras et al. proposed the use of a PMMA-based microfluidic device that generated a double-layered microdroplet bead to culture hematopoietic stem cells (HSCs) from bone marrow. This proposed method showed almost no differentiation, with few exceptions over the culture time, proving that microdroplet-based microfluidic can be a possible alternative for stem cell culture [86].

More recent cell culture approaches include the use of alternative polymer materials such as SJI-001. This alternative offers a lower autofluorescence emission hence suitable for fluorescence-based applications. The authors tested the use of SJI-001 as a component for microfluidic devices and as a potential cell scaffold. The proposed microfluidic device was fabricated using both traditional lithography and soft lithography techniques. The walls of the device were PDMS-based, and the SJI-001 or SU-8 was used for the bottom layers. HeLa cells expressing green fluorescent proteinfused histone H2B (HeLa-H2B-GFP) were cultured in both devices for 9 days, from which the SJI-001-based platform presented better adherence rate and proliferation times than its traditional counterpart [78]. 
TABLE 7: Recent BioMEMS platforms for cell culture including the type of the platform, the main components, the fabrication strategy, the mechanism of operation, and the specifics of each platform.

\begin{tabular}{|c|c|c|c|c|c|}
\hline $\begin{array}{l}\text { BioMEMS } \\
\text { platform }\end{array}$ & $\begin{array}{c}\text { Main } \\
\text { components }\end{array}$ & $\begin{array}{c}\text { Fabrication } \\
\text { strategy }\end{array}$ & Mechanism of operation & Specifics & Refs. \\
\hline $\begin{array}{l}\text { Indirect } \\
\text { temperature } \\
\text { measurement } \\
\text { LOC }\end{array}$ & $\begin{array}{l}\text { Heating } \\
\text { system } \\
\text { Temperature } \\
\text { sensor plate } \\
\text { PDMS } \\
\text { chamber } \\
\text { Electrodes }\end{array}$ & Soft lithography & $\begin{array}{l}\text { The PI control system implemented } \\
\text { porous sensors to detect the } \\
\text { temperature of the cell culture wells } \\
\text { and to generate a response from the } \\
\text { closed-loop temperature control } \\
\text { system. }\end{array}$ & $\begin{array}{l}\text { The platform enables temperature } \\
\text { control inside and outside the culture } \\
\text { system. }\end{array}$ & {$[81]$} \\
\hline $\begin{array}{l}\text { Microheater } \\
\text { chip for cell } \\
\text { culture }\end{array}$ & $\begin{array}{l}\text { Microheater } \\
\text { Culture } \\
\text { chambers } \\
\text { Electrical } \\
\text { probes }\end{array}$ & $\begin{array}{l}\text { Soft lithography } \\
\text { and laser direct- } \\
\text { write methods }\end{array}$ & $\begin{array}{l}\text { A precise square voltage pulse was } \\
\text { applied to the electrical probes in order } \\
\text { to generate a heating response from the } \\
\text { thermal stimulator. }\end{array}$ & $\begin{array}{l}\text { The device supports a wide range of } \\
\text { temperatures }\left(37-100^{\circ} \mathrm{C}\right)\end{array}$ & {$[80]$} \\
\hline $\begin{array}{l}\mu \text { Respirometer } \\
\text { LOC }\end{array}$ & $\begin{array}{l}\text { PS matrix } \\
\text { Glass wafer } \\
\text { Microsensor } \\
\quad \text { film }\end{array}$ & $\begin{array}{l}\text { DRIE, powder } \\
\text { blasting, and UV } \\
\text { excitation } \\
\text { processes }\end{array}$ & $\begin{array}{c}\mu \text { Respirometer determined the OCR of } \\
\text { mammalian cells. The film was } \\
\text { integrated into a closed microfluidic } \\
\text { chip made of oxygen-impermeable } \\
\text { materials. }\end{array}$ & $\begin{array}{c}\text { The integrated device allowed } \\
\text { continuous fluorescent measurement } \\
\text { over } 12 \text { hours. }\end{array}$ & {$[84]$} \\
\hline $\begin{array}{l}\text { Butterfly- } \\
\text { shaped } \\
\text { microchip }\end{array}$ & $\begin{array}{l}\text { Main channel } \\
\text { Test channel } \\
\text { Fluid reservoir }\end{array}$ & $\begin{array}{c}\text { Standard } \\
\text { photolithography }\end{array}$ & $\begin{array}{l}\text { The main channel width was constant } \\
\text { at some places and increased linearly at } \\
\text { other regions. The test channels were } \\
\text { all positioned at different distances } \\
\text { from each other relative to the main } \\
\text { channel. The device was used to } \\
\text { determine whether there was a } \\
\text { distance-dependent interaction } \\
\text { between a cell type and a factor. }\end{array}$ & $\begin{array}{l}\text { The device was compatible with } \\
\text { different cell types and mixtures. }\end{array}$ & {$[98]$} \\
\hline $\begin{array}{l}\text { Long-term on- } \\
\text { chip culture }\end{array}$ & $\begin{array}{l}\text { Five inlets } \\
\text { Channels } \\
\text { 3D printed } \\
\text { holder }\end{array}$ & $\begin{array}{l}\text { Photolithography } \\
\text { and wet etching }\end{array}$ & $\begin{array}{l}\text { The culture chamber was located at the } \\
\text { center of the device surrounded by two } \\
\text { porous hydrogel walls, which provided } \\
\text { the nutrients and gases from } \\
\text { neighboring channels. }\end{array}$ & $\begin{array}{l}\text { The device required no external } \\
\text { equipment and provided no shear } \\
\text { stress on the cells. }\end{array}$ & {$[82]$} \\
\hline $\begin{array}{l}\text { LEGO inspired } \\
\text { modular } \\
\text { microfluidic }\end{array}$ & $\begin{array}{l}\text { Three } \\
\text { building } \\
\text { blocks }\end{array}$ & $\begin{array}{l}\text { Conventional } \\
\text { lithography on a } \\
\text { soft lithography } \\
\text { mold }\end{array}$ & $\begin{array}{c}\text { The building blocks could be } \\
\text { interlocked via tongue and groove } \\
\text { connections and by an interference fit } \\
\text { vertical connections. To assemble the } \\
\text { double-layer blocks, the microwells } \\
\text { were attached to their respective } \\
\text { tubing, coupled and hollowed to form } \\
\text { an O-ring-free sealed microfluidic } \\
\text { system. }\end{array}$ & $\begin{array}{c}\text { The device is stiff enough to allow } \\
\text { manual coupling of the pieces, and } \\
\text { yet, its deformability accommodates } \\
\text { the interferences. }\end{array}$ & {$[75]$} \\
\hline $\begin{array}{l}\text { Gelatin-based } \\
\text { microfluidic } \\
\text { cell culture } \\
\text { chip }\end{array}$ & $\begin{array}{l}\text { PMMA } \\
\text { PDMS } \\
\text { Glass } \\
\text { NOA } \\
\text { GEL-D gelatin } \\
\text { film }\end{array}$ & Soft lithography & $\begin{array}{c}\text { The culture chambers were sealed with } \\
\text { their respective GEL-D gelatin film } \\
\text { which allowed materials of different } \\
\text { natures (PMMA, PDMS, and glass) to } \\
\text { be attached to each other and interact } \\
\text { with cells. }\end{array}$ & $\begin{array}{l}\text { The chips were found to be resistant } \\
\text { to pressure (up to } 0.7 \mathrm{MPa} \text { ) and } \\
\text { exposure to organic solvent, as well as } \\
\text { temperature (up to } 70^{\circ} \mathrm{C} \text { ) }\end{array}$ & {$[76]$} \\
\hline $\begin{array}{l}\text { Multilayered- } \\
\text { architecture } \\
\text { microfluidic } \\
\text { array }\end{array}$ & $\begin{array}{l}\text { Pneumatic } \\
\text { layers } \\
\text { Porous } \\
\text { membranes } \\
\text { 3D culture } \\
\text { layer } \\
\text { Fluidic layers }\end{array}$ & $\begin{array}{l}\text { Conventional } \\
\text { lithography and } \\
\text { soft lithography }\end{array}$ & $\begin{array}{l}\text { The porous membrane allowed the cell } \\
\text { interaction with either different drugs } \\
\text { individually or simultaneously due to } \\
\text { the incorporated top and bottom } \\
\text { valves. }\end{array}$ & $\begin{array}{l}\text { The device enables dual drug testing } \\
\text { on the same cell culture chamber and } \\
\text { is suitable for scaled-up drug testing. }\end{array}$ & {$[77]$} \\
\hline
\end{tabular}


TABLe 7: Continued.

\begin{tabular}{|c|c|c|c|}
\hline $\begin{array}{l}\text { BioMEMS } \\
\text { platform }\end{array}$ & $\begin{array}{c}\text { Main } \\
\text { components }\end{array}$ & $\begin{array}{c}\text { Fabrication } \\
\text { strategy }\end{array}$ & Mech \\
\hline $\begin{array}{l}\text { Closed } \\
\text { microfluidic } \\
\text { cell culture } \\
\text { system }\end{array}$ & $\begin{array}{c}\text { Battery } \\
\text { Peristaltic } \\
\text { pump } \\
\text { Microchannel } \\
\text { (PDMS, SJI- } \\
\text { 001) } \\
\text { Reservoir }\end{array}$ & $\begin{array}{l}\text { Conventional } \\
\text { lithography and } \\
\text { soft lithography }\end{array}$ & $\begin{array}{r}\text { Cells seeded it } \\
\text { were cultured } \\
\text { controlled }\end{array}$ \\
\hline $\begin{array}{l}\text { Microdroplet- } \\
\text { based } \\
\text { microfluidic } \\
\text { system }\end{array}$ & $\begin{array}{l}4 \text { inlets } \\
\text { Mixing area } \\
\text { Outlet }\end{array}$ & $\begin{array}{l}\text { PMMA laser } \\
\text { engraving, drill } \\
\text { pressing }\end{array}$ & $\begin{array}{r}\text { Double-layer } \\
\text { generated by } \mathrm{l} \\
\text { and flows } \mathrm{w}\end{array}$ \\
\hline $\begin{array}{l}\text { PDMS-PDA } \\
\text { treated } \\
\text { microfluidic } \\
\text { device }\end{array}$ & $\begin{array}{c}\text { Inlet } \\
\text { Outlet } \\
\text { Microchannel } \\
\text { (PDMS, PDA) }\end{array}$ & $\begin{array}{l}\text { Soft lithography } \\
\text { and PDA coating }\end{array}$ & $\begin{array}{l}\text { The culture } \mathrm{m} \\
\text { and a collagen } \\
\text { cell attachmen } \\
\text { amine group } \\
\text { them into }\end{array}$ \\
\hline \multicolumn{4}{|c|}{$\begin{array}{l}\text { DRIE: deep reactive ion etching; LOC: Lab-on-a-chip; NOA: Norland optical a } \\
\text { poly(methyl methacrylate); PI: proportional-integral; GEL: Reversible gelatin- }\end{array}$} \\
\hline \multicolumn{4}{|c|}{$\begin{array}{l}\text { BioMEMSs are powerful tools that have permitted cul- } \\
\text { turing different cell lines that would otherwise be challenging } \\
\text { to culture and analyze by traditional methods due to their } \\
\text { specific requirements. Table } 7 \text { provides some of the latest } \\
\text { advancements of } 3 \mathrm{D} \text { cell culture BioMEMS aimed at control- } \\
\text { ling the cells' microenvironment for effective culture and } \\
\text { monitoring of cells. }\end{array}$} \\
\hline
\end{tabular}

\section{Limitations of BioMEMS in Cell- Related Studies}

While numerous proof-of-concept studies are available for the use of BioMEMS devices in cell-related studies, implementation of these techniques as a widely accepted conventional approach faces serious challenges. Among the general shortcomings of BioMEMS devices, the complexity of operation is a significant obstacle preventing the widespread use of these tools. The high costs of MEMS research facilities create a burden which further limits these devices to reach their full potentials. While these miniaturized devices are compact and portable, they still require external heating, pumping, and tubing equipment to operate. Apart from the general shortcoming of BioMEMS, they fall short when certain aspects of cell studies are concerned.

Cell sorting in BioMEMS often enables higher control and a fine automatization of the process. Nevertheless, there exist certain limitations that could thwart the desired functionality and outcomes of BioMEMS devices. The need for cell labeling could potentially restrict the number of cells or particles that can be sorted by these devices [18]. Some sorting mechanisms rely on DEP which is reported to have low efficiency in cell lysing as often a high voltage is needed to enable DEP [17]. While several complex microfluidic platforms for cell sorting are reported, only a small number of them can be used directly for whole blood, saliva, or other samples. Such systems commonly need external bulky setups, elaborated designs for purification, or manual intermediate purification steps prior to sorting [10].

Cell separation is a fundamental step in the majority of cell-related studies to acquire analytes of interest from a single heterogeneous fluid. Performing cell separation in BioMEMS devices, however, poses certain challenges. One of the drawbacks of size-based cell separation is that the size of the target cells must be known beforehand. This is while the fluid might contain other cells that are in the same size range as the target cells [23]. The purification step that is often needed prior to cell separation involves manual addition of reagents into the device which may lead to errors [87]. Furthermore, the high cost of implementing equipment, the inconsistent isolation efficiency, and the possible degradation of cell viability/functionality in the separation process are reported as constraining factors in this application [88].

Cell isolation and/or trapping is another essential step in cell-related studies. BioMEMS commonly uses passive capturing or hydrodynamic force for cell isolation and/or trapping purposes $[32,35,38,89]$. These techniques face challenges including selective capturing of cells and further release of the trapped cells. Other category of BioMEMS relies on mechanisms including DEP [30], micropipettes [36], or optical tweezers [46], which can be harmful to the cells and often hard to maintain their dynamic and chemical stimuli while positioning the cells $[36,89]$.

Pairing methods often require external forces and sophisticated equipment while the undesirable effect of heat in the involving steps of operating a BioMEMS may impact the cells and complicate the long-term studying of pairing [44]. DEP, electric field, and magnetic force are commonly applied to cell pairing devices which may induce potential to damage cells as high field strength encourages disruptions in the cell, leading to unwanted lysis $[30,34,44]$. In specific designs were the cells are initially positioned in wells of opposite sides, applying an electric field may, in fact, trap the cells even 
further in their positions and act against pairing [32]. A careful control over the electric field and optimization of electrodes into a planar structure are, therefore, crucial steps in cell pairing $[32,34]$. In addition, sequential trapping commonly involves complicated 3D fabrication techniques. Such devices are reported to lack sufficient throughput, and trapping three or more cells can be challenging [46]. Moreover, in some of these designs, the spatial positioning of cells which leads to pairing in a specific order might be very challenging to achieve.

Cell-cell communication is the basis of various diseases including cancer, autoimmune disorders, and diabetes [53]. A careful analysis of communication between cells is, therefore, crucial for understanding the nature of these illnesses. The major limitation of BioMEMS which is aimed at cellcell communication is the complex microenvironments which they need to reproduce in order to accurately mimic the physiological models $[55,90]$. Other challenges involve the simultaneous culture of multiple cell types, parallelization, and automation of the process [55].

Cell differentiation and/or identification BioMEMS typically relies on techniques such as impedance flow cytometry, which has the limitation of identifying cells through nonspecific electrical properties [70]. Impedance-based flow cytometers are also unable to track temporal changes in properties of individual cells [91]. Human stem cell-derived differentiation in a BioMEMS requires hepatocyte culture platform and long-term culture for robust applications [67]. Furthermore, some BioMEMSs apply dynamic bioreactors to differentiate cells which could introduce hydrodynamic shear stress hence decreasing the cell viability [92].

Cell culture is one of the most fundamental protocols performed in BioMEMS for all cell-related studies. However, this basic step also suffers from certain limitations of these devices. Majority of the BioMEMS platforms are made of PDMS through soft lithography fabrication process. PDMS, however, can absorb molecules and interfere with the assay [93]. Moreover, current 3D culture devices have a major limitation of implementing barriers between fluids and cells to eliminate shear stress on the cells due to fluid flow and long-term culture [94]. Perfusion of more than one growth medium which is sometimes required when coculturing multiple cell lines can also pose a great challenge in such devices.

\section{Conclusions}

BioMEMS enables new possibilities for monitoring, accommodating, and modulating cell units in unprecedented ways alongside with new prospects of development of integrated devices that can automatize and significantly improve the current tools for biological studies. In this review article, the latest developments of BioMEMS platforms for cell-related studies are covered with specific emphasis on cell sorting, cell separation, cell isolation or trapping, cell pairing, cell-cell communication, cell differentiation and identification, and cell culture. For each cell-related application, we review not only the advancement of such devices, but also the main components of the device, the fabrication strategies, and the mechanism of operation, as well as remarks on each plat- form. This review also summarizes some of the general and specific shortcomings of the BioMEMS platforms in cellrelated studies which can further advance the optimization process of these tools.

\section{Conflicts of Interest}

The authors declare no conflict of interest.

\section{Authors' Contributions}

S.H. proposed the topic and outlines of the review paper. R.G., A.S.C., D.A., S.R., and J.A.G. performed the literature review and wrote the draft. R.G. and A.S.C. wrote the analytical sections and edited the entire draft. S.H. supervised the work and shaped up the manuscript.

\section{Acknowledgments}

The authors would also like to acknowledge the financial and technical support of Writing Lab, Institute for the Future of Education, Tecnologico de Monterrey, Mexico.

\section{References}

[1] Y. Yanagida, "MEMS/NEMS-based devices for bio-measurements," Electrochemistry, vol. 85, no. 9, pp. 572-579, 2017.

[2] S. Saliterman, Fundamentals of BioMEMS and Medical Microdevices, Wiley, 2006.

[3] E. W. K. Young and D. J. Beebe, "Fundamentals of microfluidic cell culture in controlled microenvironments," Chemical Society Reviews, vol. 39, no. 3, pp. 1036-1048, 2010.

[4] M. J. Tomlinson, S. Tomlinson, X. B. Yang, and J. Kirkham, "Cell separation: terminology and practical considerations," Journal of Tissue Engineering, vol. 4, 14 pages, 2013.

[5] S. Hosseini, F. Ibrahim, I. Djordjevic, and L. H. Koole, "Recent advances in surface functionalization techniques on polymethacrylate materials for optical biosensor applications," Analyst, vol. 139, no. 12, pp. 2933-2943, 2014.

[6] C. Wyatt Shields IV, C. D. Reyes, and G. P. López, "Microfluidic cell sorting: a review of the advances in the separation of cells from debulking to rare cell isolation," Lab on a Chip, vol. 15, no. 5, pp. 1230-1249, 2015.

[7] M. E. Piyasena and S. W. Graves, "The intersection of flow cytometry with microfluidics and microfabrication," Lab on a Chip, vol. 14, no. 6, pp. 1044-1059, 2014.

[8] J. El-Ali, P. K. Sorger, and K. F. Jensen, "Cells on chips," Nature, vol. 442, no. 7101, pp. 403-411, 2006.

[9] L. Lin, Q. Chen, and J. Sun, "Micro/nanofluidics-enabled single-cell biochemical analysis," TrAC Trends in Analytical Chemistry, vol. 99, pp. 66-74, 2018.

[10] Z. T. F. Yu, J. G. Joseph, S. X. Liu et al., "Centrifugal microfluidics for sorting immune cells from whole blood," Sensors and Actuators B: Chemical, vol. 245, pp. 1050-1061, 2017.

[11] X. Ding and T. J. Huang, "Microfluidic manipulation and sorting of particles using tunable standing surface acoustic wave," Google Patents, March 2017.

[12] R. Garcia-Ramirez and S. Hosseini, "History of Biomicroelectromechanical Systems (BioMEMS)," in BioMEMS, Springer, Singapore, 2021. 
[13] M. C. Jo and R. Guldiken, "Effects of polydimethylsiloxane (PDMS) microchannels on surface acoustic wave- based microfluidic devices," Microelectronic Engineering, vol. 113, pp. 98-104, 2014.

[14] W. Gao, B. E.-F. de Ávila, L. Zhang, and J. Wang, “Targeting and isolation of cancer cells using micro/nanomotors," Advanced Drug Delivery Reviews, vol. 125, pp. 94-101, 2018.

[15] Y. Song, H. Yin, and W. E. Huang, "Raman activated cell sorting," Current Opinion in Chemical Biology, vol. 33, pp. 1-8, 2016.

[16] K. S. Lee, M. Palatinszky, F. C. Pereira et al., “An automated Raman-based platform for the sorting of live cells by functional properties," Nature Microbiology, vol. 4, no. 6, pp. 1035-1048, 2019.

[17] Y. Yildizhan, N. Erdem, M. Islam, R. Martinez-Duarte, and M. Elitas, "Dielectrophoretic separation of live and dead monocytes using 3D carbon-electrodes," Sensors, vol. 17, no. 11, p. 2691, 2017.

[18] S. Hung, C. H. Hsu, and C. Chen, "Cell sorting in microfluidic systems using dielectrophoresis," in IEEE 15th International Conference on Nanotechnology (IEEE-NANO), pp. 872-875, Rome, Italy, 2015.

[19] X. Nie, Y. Luo, P. Shen, C. Han, D. Yu, and X. Xing, "Highthroughput dielectrophoretic cell sorting assisted by cell sliding on scalable electrode tracks made of conducting-PDMS," Sensors and Actuators B: Chemical, vol. 327, article 128873, 2021.

[20] I. I. Hosseini, M. Moghimi Zand, A. A. Ebadi, and M. Fathipour, "Cell properties assessment using optimized dielectrophoresis-based cell stretching and lumped mechanical modeling," Scientific Reports, vol. 11, no. 1, p. 2341, 2021.

[21] S. Barkam, S. Saraf, and S. Seal, "Fabricated micro-nano devices for in vivo and in vitro biomedical applications," Wiley Interdisciplinary Reviews: Nanomedicine and Nanobiotechnology, vol. 5, no. 6, pp. 544-568, 2013.

[22] T. M. Geislinger and T. Franke, "Sorting of circulating tumor cells (MV3-melanoma) and red blood cells using non-inertial lift," Biomicrofluidics, vol. 7, no. 4, p. 044120, 2013.

[23] G. E. Hvichia, Z. Parveen, C. Wagner et al., "A novel microfluidic platform for size and deformability based separation and the subsequent molecular characterization of viable circulating tumor cells," International Journal of Cancer, vol. 138, no. 12, pp. 2894-2904, 2016.

[24] A. Salmanzadeh, "Isolation of rare cells through their dielectrophoretic signature," Journal of Membrane Science \& Technology, vol. 3, no. 1, pp. 1-4, 2013.

[25] H. Song, J. M. Rosano, Y. Wang et al., "Continuous-flow sorting of stem cells and differentiation products based on dielectrophoresis," Lab on a Chip, vol. 15, no. 5, pp. 1320-1328, 2015.

[26] Z. Zhu, D. Wu, S. Li et al., "A polymer-film inertial microfluidic sorter fabricated by jigsaw puzzle method for precise sizebased cell separation," Analytica Chimica Acta, vol. 1143, pp. 306-314, 2021.

[27] S. Razavi Bazaz, O. Rouhi, M. A. Raoufi et al., "3D printing of inertial microfluidic devices," Scientific Reports, vol. 10, no. 5929, pp. 1-14, 2020.

[28] S. Zhao, M. Wu, S. Yang et al., "A disposable acoustofluidic chip for nano/microparticle separation using unidirectional acoustic transducers," Lab on a Chip, vol. 20, no. 7, pp. 1298-1308, 2020.
[29] C. Yousuff, E. Ho, K. Ismail Hussain, and N. Hamid, "Microfluidic platform for cell isolation and manipulation based on cell properties," Micromachines, vol. 8, no. 1, p. 15, 2017.

[30] M. Punjiya, H. R. Nejad, J. Mathews, M. Levin, and S. Sonkusale, "A flow through device for simultaneous dielectrophoretic cell trapping and AC electroporation," Scientific Reports, vol. 9, no. 1, p. 11988, 2019.

[31] W. Espulgar, Y. Yamaguchi, W. Aoki et al., "Single cell trapping and cell-cell interaction monitoring of cardiomyocytes in a designed microfluidic chip," Sensors and Actuators B: Chemical, vol. 207, no. Part A, pp. 43-50, 2015.

[32] C. Wu, R. Chen, Y. Liu, Z. Yu, Y. Jiang, and X. Cheng, “A planar dielectrophoresis-based chip for high-throughput cell pairing," Lab on a Chip, vol. 17, no. 23, pp. 4008-4014, 2017.

[33] X. Guo and R. Zhu, "Controllably moving individual living cell in an array by modulating signal phase difference based on dielectrophoresis," Biosensors \& Bioelectronics, vol. 68, pp. 529$535,2015$.

[34] L. Huang, P. Zhao, S. Bian et al., "A novel bioMEMS device for efficient on-chip single cell loading and 3D rotation," in 2017 IEEE 30th International Conference on Micro Electro Mechanical Systems (MEMS), pp. 490-493, Las Vegas, NV, USA, January 2017.

[35] L. Lin, Y. S. Chu, J. P. Thiery, C. T. Lim, and I. Rodriguez, "Microfluidic cell trap array for controlled positioning of single cells on adhesive micropatterns," Lab on a Chip, vol. 13, no. 4, pp. 714-721, 2013.

[36] S. S. Bithi and S. A. Vanapalli, "Microfluidic cell isolation technology for drug testing of single tumor cells and their clusters," Scientific Reports, vol. 7, no. 1, article 41707, 2017.

[37] Z. H. Fan, J. I. Varillas, J. Zhang, K. Chen, and T. J. George, "Tumor cell isolation in microfluidic devices for cancer treatment monitoring," in 2017 IEEE 30th International Conference on Micro Electro Mechanical Systems (MEMS), pp. 1264-1267, Las Vegas, NV, January 2017.

[38] C. L. Hisey, O. Mitxelena-Iribarren, M. Martínez-Calderón et al., "A versatile cancer cell trapping and 1D migration assay in a microfluidic device," Biomicrofluidics, vol. 13, no. 4, article 044105, 2019.

[39] Y. Huang, N. T. Nguyen, K. S. Lok et al., "Multiarray cell stretching platform for high-magnification real-time imaging," Nanomedicine, vol. 8, no. 4, pp. 543-553, 2013.

[40] Y. Y. Chiang, Y. C. Teng, Z. Y. Su, H. Y. Hsueh, and K. H. Tu, "Hydrodynamic Snaring Array for Trapping and Perfusion Culture of Single Cell," Sensors and Actuators B: Chemical, vol. 312, article 127966, 2020.

[41] L. Romita, S. Thompson, and D. K. Hwang, "Rapid fabrication of sieved microwells and cross-flow microparticle trapping," Scientific Reports, vol. 10, no. 1, p. 15687, 2020.

[42] R. Luo, S. Pashapour, O. Staufer, I. Platzman, and J. P. Spatz, "Polymer-based porous microcapsules as bacterial traps," Advanced Functional Materials, vol. 30, no. 17, article 1908855, 2020.

[43] A. M. Skelley, O. Kirak, H. Suh, R. Jaenisch, and J. Voldman, "Microfluidic control of cell pairing and fusion," Nature Methods, vol. 6, no. 2, pp. 147-152, 2009.

[44] L. Li, H. Wang, L. Huang, S. A. Michael, W. Huang, and $\mathrm{H}$. Wu, "A controllable, centrifugal-based hydrodynamic microfluidic chip for cell-pairing and studying long-term communications between single cells," Analytical Chemistry, vol. 91, no. 24, pp. 15908-15914, 2019. 
[45] J. Zhu, Y. Wang, P. Chen, H. Su, W. Du, and B. F. Liu, "Highly efficient microfluidic device for cell trapping and pairing towards cell-cell communication analysis," Sensors and Actuators B: Chemical, vol. 283, pp. 685-692, 2019.

[46] Y. Abe, K. Kamiya, T. Osaki, R. Kawano, N. Miki, and S. Takeuchi, "Mechanical cell pairing system by sliding parylene rails," in 2014 IEEE 27th International Conference on Micro Electro Mechanical Systems (MEMS), pp. 185-187, San Francisco, CA, USA, January 2014.

[47] B. Dura, Y. Liu, and J. Voldman, "Deformability-based microfluidic cell pairing and fusion," Lab on a Chip, vol. 14, no. 15, pp. 2783-2790, 2014.

[48] H. Hu, D. Eustace, and C. A. Merten, "Efficient cell pairing in droplets using dual-color sorting," Lab on a Chip, vol. 15, no. 20, pp. 3989-3993, 2015.

[49] H. Zhang, A. R. Guzman, J. A. Wippold et al., "An ultra highefficiency droplet microfluidics platform using automatically synchronized droplet pairing and merging," Lab on a Chip, vol. 20, no. 21, pp. 3948-3959, 2020.

[50] W. He, L. Huang, Y. Feng, F. Liang, W. Ding, and W. Wang, "Highly integrated microfluidic device for cell pairing, fusion and culture," Biomicrofluidics, vol. 13, no. 5, article 054109, 2019.

[51] H. Babahosseini, T. Misteli, and D. L. Devoe, "Microfluidic ondemand droplet generation, storage, retrieval, and merging for single-cell pairing," Lab on a Chip, vol. 19, no. 3, pp. 493-502, 2019.

[52] Y. Zhou, N. Shao, R. Bessa de Castro et al., "Evaluation of single-cell cytokine secretion and cell-cell interactions with a hierarchical loading microwell chip," Cell Reports, vol. 31, no. 4, article 107574, 2020.

[53] T. Pawson, "Protein modules and signalling networks," Nature, vol. 373, no. 6515, pp. 573-580, 1995.

[54] F. Guo, J. B. French, P. Li et al., "Probing cell-cell communication with microfluidic devices," Lab on a Chip, vol. 13, no. 16, pp. 3152-3162, 2013.

[55] M. Rothbauer, H. Zirath, and P. Ertl, "Recent advances in microfluidic technologies for cell-to-cell interaction studies," Lab on a Chip, vol. 18, no. 2, pp. 249-270, 2018.

[56] H. Ma, T. Liu, J. Qin, and B. Lin, "Characterization of the interaction between fibroblasts and tumor cells on a microfluidic co-culture device," Electrophoresis, vol. 31, no. 10, pp. 1599$1605,2010$.

[57] G. Fang, H. Lu, H. Aboulkheyr Es et al., "Unidirectional intercellular communication on a microfluidic chip," Biosensors \& Bioelectronics, vol. 175, article 112833, 2021.

[58] S. M. Rahman, J. M. Campbell, R. N. Coates et al., "Evaluation of intercellular communication between breast cancer cells and adipose-derived stem cellsviapassive diffusion in a twolayer microfluidic device," Lab on a Chip, vol. 20, no. 11, pp. 2009-2019, 2020.

[59] L. Businaro, G. Schiavoni, V. Lucarini et al., "Cross talk between cancer and immune cells: exploring complex dynamics in a microfluidic environment," Lab on a Chip, vol. 13, no. 2, pp. 229-239, 2013.

[60] P. Liu, Y. W. Cao, S. D. Zhang et al., "A bladder cancer microenvironment simulation system based on a microfluidic co-culture model," Oncotarget, vol. 6, no. 35, pp. 37695-37705, 2015.

[61] A. D. Blackwell, M. A. Tamayo, B. Beheim et al., "Helminth infection, fecundity, and age of first pregnancy in women," Science, vol. 350, no. 6263, pp. 970-972, 2015.
[62] A. Taylor, D. Dieterich, H. Ito, S. Kim, and E. M. Schuman, "Microfluidic local perfusion chambers for the visualization and manipulation of synapses," Neuron, vol. 66, no. 1, pp. 57-68, 2010.

[63] A. Schneider, T. Scharnweber, D. Cammann, B. Rapp, S. Giselbrecht, and C. M. Niemeyer, "Multiscale microstructure for investigation of cell-cell communication," Small Methods, vol. 4, no. 12, article 2000647, 2020.

[64] H. Higashimori and Y. Yang, "Imaging analysis of neuron to glia interaction in microfluidic culture platform (MCP)-based neuronal axon and glia co-culture system," JoVE, vol. 68, article e4448, 2012.

[65] J. Park, H. Koito, J. Li, and A. Han, "Multi-compartment neuron-glia co-culture platform for localized CNS axon-glia interaction study," Lab on a Chip, vol. 12, no. 18, pp. 32963304, 2012.

[66] I. Bilican, M. T. Guler, M. Serhatlioglu, T. Kirindi, and C. Elbuken, "Focusing-free impedimetric differentiation of red blood cells and leukemia cells: a system optimization," Sensors and Actuators B: Chemical, vol. 307, article 127531, 2020.

[67] L. J. Y. Ong, L. Jin, P. K. Singh et al., “A pump-free microfluidic 3D perfusion platform for the efficient differentiation of human hepatocyte-like cells," Biotechnology and Bioengineering, vol. 114, no. 10, pp. 2360-2370, 2017.

[68] A. Jupe, S. Kahnert, M. Figge et al., "Development of a piezoelectric flexural plate-wave (FPW) biomems-sensor for rapid point-of-care diagnostics," NATO Science for Peace and Security Series A: Chemistry and Biology, pp. 199-212, 2018.

[69] R. W. R. L. Gajasinghe, O. Tigli, M. Jones, and T. Ince, "Labelfree tumor cell detection and differentiation based on electrical impedance spectroscopy," in 2016 IEEE SENSORS, pp. 3-5, Orlando, FL, USA, 2017.

[70] F. Liu, K. C. Pawan, G. Zhang, and J. Zhe, "A microfluidic sensor for single cell detection in a continuous flow," in 2017 19th International Conference on Solid-State Sensors, Actuators and Microsystems (TRANSDUCERS), pp. 194-197, Kaohsiung, Taiwan, Jul. 2017.

[71] P. Ghassemi, X. Ren, B. M. Foster, B. A. Kerr, and M. Agah, "Post-enrichment circulating tumor cell detection and enumeration via deformability impedance cytometry," Biosensors \& Bioelectronics, vol. 150, article 111868, 2020.

[72] Q. Huang, S. Mao, M. Khan, W. Li, Q. Zhang, and J. M. Lin, "Single-cell identification by microfluidic-based: in situ extracting and online mass spectrometric analysis of phospholipids expression," Chemical Science, vol. 11, no. 1, pp. 253256, 2020.

[73] Y. Zhu, H. Xu, X. Wei, and H. He, "Single-cell detection and photostimulation on a microfluidic chip aided with gold nanorods," Cytometry Part A, vol. 97, no. 1, pp. 3945, 2020.

[74] P. B. Gahan, "Molecular biology of the cell (4th edn) B. Alberts, A. Johnson, J. Lewis, K. Roberts and P. Walter (eds), Garland Science, 1463 pp., ISBN 0-8153-4072-9 (paperback) (2002)," Cell Biochemistry and Function, vol. 23, no. 2, pp. 150-150, 2005.

[75] X. Xie, S. Maharjan, S. Liu, Y. Zhang, and C. Livermore, "A modular, reconfigurable microfabricated assembly platform for microfluidic transport and multitype cell culture and drug Testing," Micromachines, vol. 11, no. 1, p. 2, 2020.

[76] G. Pitingolo, A. Riaud, C. Nastruzzi, and V. Taly, "Tunable and reversible gelatin-based bonding for microfluidic cell culture," 
Advanced Engineering Materials, vol. 21, no. 8, p. 1900145, 2019.

[77] H. C. Chang, C. H. Lin, D. Juang et al., "Multilayer architecture microfluidic network array for combinatorial drug testing on 3D-cultured cells," Biofabrication, vol. 11, no. 3, article 035024, 2019.

[78] H. Ueno, K. Maruo, M. Inoue, H. Kotera, and T. Suzuki, "Cell culture on low-fluorescence and high-resolution photoresist," Micromachines, vol. 11, no. 6, p. 571, 2020.

[79] J. E. Swain, "Decisions for the IVF laboratory: comparative analysis of embryo culture incubators," Reproductive Biomedicine Online, vol. 28, no. 5, pp. 535-547, 2014.

[80] D. Nieto, P. McGlynn, M. de la Fuente, R. Lopez-Lopez, and G. M. O'connor, "Laser microfabrication of a microheater chip for cell culture outside a cell incubator," Colloids and Surfaces. B, Biointerfaces, vol. 154, pp. 263-269, 2017.

[81] A.-J. Maki, T. Ryynanen, J. Verho, J. Kreutzer, J. Lekkala, and P. J. Kallio, "Indirect temperature measurement and control method for cell culture devices," IEEE Transactions on Automation Science and Engineering, vol. 15, no. 2, pp. 420-429, 2018.

[82] F. Bunge, S. van den Driesche, and M. J. Vellekoop, "Microfluidic platform for the long-term on-chip cultivation of mammalian cells for Lab-on-a-Chip applications," Sensors, vol. 17, no. 7, pp. 1603-1615, 2017.

[83] R. D. Guarino, L. E. Dike, T. A. Haq, J. A. Rowley, J. B. Pitner, and M. R. Timmins, "Method for determining oxygen consumption rates of static cultures from microplate measurements of pericellular dissolved oxygen concentration," Biotechnology and Bioengineering, vol. 86, no. 7, pp. 775-787, 2004.

[84] F. Bunge, S. van den Driesche, A. Waite, U. Mirastschijski, and M. J. Vellekoop, " $\mu$ Respirometer to determine the oxygen consumption rate of mammalian cells in a microfluidic cell culture," in 2017 IEEE 30th International Conference on Micro Electro Mechanical Systems (MEMS), pp. 414-417, Las Vegas, NV, 2017.

[85] M. Dabaghi, S. Shahriari, N. Saraei et al., "Surface modification of PDMS-based microfluidic devices with collagen using polydopamine as a spacer to enhance primary human bronchial epithelial cell adhesion," Micromachines, vol. 12, no. 2, p. 132, 2021

[86] P. Carreras, I. González, M. Gallardo et al., "Long-term human hematopoietic stem cell culture in microdroplets," Micromachines, vol. 12, no. 1, p. 90, 2021.

[87] R. Tang, H. Yang, J. R. Choi et al., "Paper-based device with on-chip reagent storage for rapid extraction of DNA from biological samples," Microchimica Acta, vol. 184, no. 7, pp. 21412150, 2017.

[88] B. K. Lin, S. M. McFaul, C. Jin, P. C. Black, and H. Ma, "Highly selective biomechanical separation of cancer cells from leukocytes using microfluidic ratchets and hydrodynamic concentrator," Biomicrofluidics, vol. 7, no. 3, article 034114, 2013.

[89] Y. Wang, J. Zhu, P. Chen et al., "A microfluidic platform with pneumatically switchable single-cell traps for selective intracellular signals probing," Talanta, vol. 192, pp. 431-438, 2019.

[90] B. M. Baker and C. S. Chen, "Deconstructing the third dimension - how 3D culture microenvironments alter cellular cues," Journal of Cell Science, vol. 125, no. 13, pp. 3015-3024, 2012.

[91] Y. Zhou, S. Basu, E. Laue, and A. A. Seshia, "Single cell studies of mouse embryonic stem cell (mESC) differentiation by elec- trical impedance measurements in a microfluidic device," Biosensors \& Bioelectronics, vol. 81, pp. 249-258, 2016.

[92] C. Mckee and G. R. Chaudhry, "Advances and challenges in stem cell culture," Colloids and Surfaces. B, Biointerfaces, vol. 159, pp. 62-77, 2017.

[93] K. P. Valente, S. Khetani, A. R. Kolahchi, A. Sanati-nezhad, A. Suleman, and M. Akbari, "Microfluidic technologies for anticancer drug studies," Drug Discovery Today, vol. 22, no. 11, pp. 1654-1670, 2017.

[94] A. J. Bastiaens, J. Frimat, T. Van Nunen, and B. Schurink, "Advancing a MEMS-based 3D cell culture system for in vitro Neuro-Electrophysiological recordings," Frontiers in Mechanical Engineering, vol. 4, pp. 1-10, 2018.

[95] M. Li, H. E. Muñoz, K. Goda, and D. Di Carlo, "Shape-based separation of microalga _Euglena gracilis_ using inertial microfluidics," Scientific Reports, vol. 7, no. 1, article 10802, 2017.

[96] X. Lu and X. Xuan, "Continuous microfluidic particle separation via elasto-inertial pinched flow fractionation," Analytical Chemistry, vol. 87, no. 12, pp. 6389-6396, 2015.

[97] S. McCutcheon, R. Majeska, M. Schaffler, and M. Vazquez, "A multiscale fluidic device for the study of dendrite-mediated cell to cell communication," Biomedical Microdevices, vol. 19, no. 3, p. 71, 2017.

[98] E. Yildiz-Ozturk, S. Gulce-Iz, M. Anil, and O. Yesil-Celiktas, "Cytotoxic responses of carnosic acid and doxorubicin on breast cancer cells in butterfly-shaped microchips in comparison to 2D and 3D culture," Cytotechnology, vol. 69, no. 2, pp. 337-347, 2017. 